\title{
Physiological conditions influencing regenerative potential of stem cells
}

\author{
Gabriella Spaltro ${ }^{1}$, Daniele Avitabile ${ }^{1}$, Elena De Falco ${ }^{2}$, Elisa Gambini ${ }^{1}$ \\ ${ }_{1}^{1}$ Vascular Biology and Regenerative Medicine Unit, Centro Cardiologico Monzino, IRCCS, Milan, Italy, \\ ${ }^{2}$ Department of Medical-Surgical Sciences and Biotechnologies, Sapienza University of Rome, Italy
}

\section{TABLE OF CONTENTS}

1. Abstract

2. Introduction

2.1. Stem cells used for cardiac regeneration

3. Physiological conditions influencing stem cell regenerative potential of stem cell

3.1. Aging

3.2. Metabolic syndrome

4. Strategies to enhance stem cell regenerative potential

4.1. Pretreating stem cells before infusion

4.2. Treatment of the target tissue: how to rejuvenate cardiac tissue

5. Alternatives to autologous cell therapy

6. Conclusions and future perspectives

7. Acknowledgements

8. References

\section{ABSTRACT}

Stem cells are being used in the treatment of cardivovascular diseases. Here, we review the physiologic and pathologic conditions that impact the regenerative potential of stem cells in the treatment of cardiovascular diseases which include the influence of donor age and the presence of metabolic syndromes. We will also discuss strategies such as pretreatment of the recipient tissue or autologous or allogeneic stem cells by growth factors or drugs and by providing a synthetic scaffold and genetic modifications that impact the regenerative potential of stem cells. Finally, we will evaluate the current state of treatment of acute or chronic cardiovascular diseases with allogeneic stem cells.

\section{INTRODUCTION}

Ischemic heart failure is the leading cause of hospitalization and death in Western countries $(1,2)$. So far, the employment of current clinical therapies has been useful to slow the progression of cardiovascular diseases, however the regeneration of hearth tissue after an ischemic insult is still to be solved. Stem cell therapy has proven to be a promising option for the treatment of cardiovascular diseases of ischemic origin, by promoting cardiac tissue regeneration (3). Cardiac function and cardiomyogenic and vascular cell lineage differentiation have been improved by both bone marrow (BM)-derived and tissue specific stem cells in experimental models. Additionally, the capacity of stem cells to secrete paracrine pro-angiogenic and cardioprotective molecules has also been demonstrated. Although BM-derived cells are the most used cell type in cell therapy-based applications, non-BM or tissue specific stem cell types including mesenchymal stem cells (MSCs), endothelial progenitor cells (EPCs), hematopoietic stem cells (HSCs) and cardiac tissue derived progenitors (CPCs) are also under clinical evaluation.

A major limitation in the field of cell therapy is determined by the fact that the functionality of stem cells largely depends on the pathophysiological state of the donors. Metabolism is known to markedly influence stem cell fate and function (4). Indeed, aging, metabolic syndrome and diabetes represent major changes in metabolism that are associated with cardiovascular diseases and affect the quantity and quality of stem cells, thus limiting their therapeutic potential. In light of this, several research groups are currently attempting to further investigate this major issue. Presently, three main strategies have been proposed: 1) development of preconditioning treatments to restore or improve the function of 'sick' cells before their reinfusion, 2) preparation of the recipient tissue by treating the patient in order to increase the engraftment of transplanted cells, 3) use of allogeneic rather than autologous cells.

\subsection{Stem cells for cardiac regeneration}

Stem cells hold the ability to self-renew and to differentiate into multiple lineages according to their degree of stemness. Over the years accumulating evidences have suggested that almost all tissues (heart, adipose, brain, spleen, liver, kidney, lung, muscle, thymus, 
pancreas, umbilical cord, placenta, dental pulp, skin and a variety of fetal tissues) retain niches of "resident" stem cells similar to those observed in BM $(4,5)$. Consequently, the discovery of a cardiac stem cell (CSC) niche residing in the adult heart has changed the dogma that the heart is a post-mitotic organ devoid of regeneration potential (5). CSCs have been proven to self-renew, to possess clonogenic and multipotent ability and to differentiate both in vitro and in vivo into cardiomyocytes, smooth muscle cells and endothelial cells (5-10). Indeed, since the first discovery of c-kit ${ }^{+}$CSCs, different types of CSCs and cardiac progenitor cell populations have been identified both in rodents and humans $(5,9,11)$, including a mixed population named cardiospheres containing $\mathrm{c}^{\mathrm{k}} \mathrm{kit}^{+}$cells and cells expressing the stromal cell marker CD105 (12). Human c-kit ${ }^{+}$CSCs are the first cardiac resident population which has been used in a clinical trials (SCIPIO and CADUCEUS). The SCIPIO trial is a randomized phase I trial testing the safety and feasibility of using autologous $\mathrm{c}^{-\mathrm{kit}^{+}} \mathrm{CSCs}$ to treat ischemic cardiomyopathy. Despite the small number of patients enrolled, the trial has demonstrated that the infusion of CSCs is safe and feasible, reduces infarct size, improves regional and global LV function and the viability of the myocardium for up to 1 year after injection $(13,14)$. A second phase I trial named CADUCEUS, based on the use of human cardiosphere derived cells (CDCs), which contain $\mathrm{c}-\mathrm{kit}^{+} \mathrm{CSCs}$, has been conducted to improve safety and to verify the preliminary efficacy of intracoronary administration of autologous CDCs. The results of the CADUCEUS trial has proven that the use of CDCs is safe resulting in decreased scar size, increased myocardium viability and improved regional function of the infarcted myocardium 1 year post-treatment (15).

Despite this, it is hard to undoubtedly assess the best stem cell source to repair a damaged heart. In fact, besides CDCs and CSCs, other non-cardiac stem cell populations have been undergoing clinical evaluation. However, BM-derived cells (including HSCs, MSCs and EPCs) and adipose tissue derived mesenchymal stem cells (A-MSCs) still represent the main cell types that have been studied to regenerate a damaged myocardium.

Human HSCs, identified by the expression of surface markers such as CD133, CD34, or CD117 (c-kit), have been demonstrated to exhibit in vitro transdifferentiation ability towards myocardial lineages and therefore are intensively studied for the treatment of cardiac failure (16). Clinical trials conducted so far, using BM-derived HSCs have proved the safety and feasibility of this cell population for cardiac applications (8). Similarly, EPCs (another BM-derived stem cell population) have been extensively investigated for cardiac regenerative purposes (17). EPCs are angiogenic cells capable of differentiating into mature endothelial cells and promote the repair of damaged endothelium $(18,19)$. Several clinical trials have tested the use of these cells in the treatment of cardiovascular diseases. TOPCARE-AMI is the first randomized clinical study examining the use of EPCs for the treatment of acute myocardial infarction. This study has demonstrated that EPCs are able to enhance left ventricular ejection fractions and to reduce infarct size in the absence of cardiac hypertrophy (20); in a similar setting, REPAIR-AMI has demonstrated that transplantation of EPC abrogates early LV remodeling after AMI. The MAGIC and BOOST trials have shown regeneration and angiogenesis after G-CSF and intracoronary BM-mononuclear cell infusion in patients with myocardial infarction (21-23).

An increasing body of evidence suggests that non EPC-like cells such as MSCs represents a promising stem cell source, particularly suitable for regenerative medicine applications. MSCs have been identified as a multipotent population showing plastic-adherent properties, ability to generate single-cell colonies (24) and mesodermal differentiation potential (chondrogenic, adipogenic and osteogenic differentiation) (25-27). To date, MSC phenotype cannot be identified by a specific single marker. Accordingly, in 2005 the International Society for Cellular Therapy (ISCT) published a position paper, defining the minimum criteria to define the MSC population; positive for CD73, CD90 and CD105 and negative for hematopoietic markers, such as CD45, CD34 and CD19 (28). Intriguingly, MSCs have been demonstrated to differentiate towards the cardiac lineage both in vitro and in vivo $(26,29-39)$ and the interest for this cell type is increasing due to their immune-modulating properties. Thus, MSCs are under investigation to test both autologous and allogeneic use in different clinical trials. Currently, autologous and allogeneic MSCs are examined in the POSEIDON-DCM trial as treatment options for non-ischemic heart failure.

Among the non BM-derived stem cells, a growing interest is focused on adipose tissue-derived stem cells (A-MSCs) described for the first time by Zuk et al. in 2001 (28). A-MSCs have been located in the vessel walls and perivascular niches (40) present in fat obtained during liposuction (a minimally invasive and low risk procedure). Interestingly, A-MSCs share many features with BM-derived MSCs. Indeed, with the exception of the surface marker CD34 (41), A-MSCs possess all the minimal criteria defined by ISCT for identifying MSCs $(27,28)$. Several studies have reported the ability of rabbit, mice and human A-MSCs to differentiate in vitro into cardiomyocytes under specific culture conditions (4247). Moreover, in some cases, A-MSCs have also been shown to acquire pacemaker activity, although at low percentages (48). Similarly to BM-derived MSCs, A-MSCs improve cardiac function in rodent and pig models of MI, although it is unclear whether their beneficial activity is mainly the result of direct trans-differentiation into new cardiomyocytes, endothelial and smooth muscle cells or the indirect consequence of their paracrine action in 
combination with their ability to exert a feeder-like support within the cardiac tissue $(26,49-54)$. Several phase I/II studies are currently ongoing to test the safety, feasibility, and efficacy of A-MSCs in cardiovascular diseases. APOLLO and PRECISE trials using freshly isolated A-MSCs have reported a trend for increased cardiac function in terms of perfusion, reduction of scar (APOLLO trial) and increased wall motion score index evaluated by magnetic resonance (PRECISE trial) $(55,56)$, whereas MyStromalCell Trial has tested the intramyocardial (IM) injection of culture-expanded A-MSCs stimulated with VEGF-A $_{165}$ (57). The ADVANCE study was the first trial to evaluate the efficacy of A-MSC-based cell therapy in patients with AMI. Patients were treated or not with A-MSCs and the amount of infarct size reduction was assessed at 6 months (58). Unfortunately, the trial was terminated due to difficulties in recruiting patients and reaching the target enrollment of 216 patients which stood at 23 patients when the trial was terminated.

\section{PHYSIOLOGICAL CONDITIONS INFLUENCING STEM CELL REGENERATIVE POTENTIAL OF STEM CELLS}

There is compelling evidence that aging, metabolic and cardiovascular diseases are critically interconnected. Indeed, patients experiencing metabolic and cardiovascular diseases age faster. Furthermore, a clear association between cardiovascular risk and increased age has been largely reported (59). The average lifespan of humans is increasing, and the percentage of older people will continue to grow in the next 20 years. Therefore it is easily estimated that cardiovascular diseases will still represent the leading cause of death in people over 65 years of age (60). The scientific literature to date suggests that metabolism can profoundly influence the fate of stem cells (61-65). As a consequence, natural or pathological changes in metabolism associated with natural aging or with metabolic diseases of donors are predicted to negatively impact the quantity and quality of stem and progenitor cells, thus limiting their therapeutic potential (66-69).

\subsection{Aging}

Aging is a physiological process that affects all organs and tissues, leading to the deterioration of their normal function and to the inhibition or impairment of repair mechanisms. Indeed, the functionality of adult stem cells decreases with age which impact the normal tissue regeneration rate $(68,70,71-73)$. Myocardial aging has been proposed as an imbalance between the growth and death of myocytes, resulting in the accumulation of senescent myocytes with decreased contractile function (74). Cell senescence affects not only myocytes but also CPCs (74). In fact, cardiac aging correlates with a decreased number of active resident stem cells that display shorter telomeres, increased genomic instability, DNA damage, p53 activation and consequent cell cycle arrest $(75,76)$. Aged CPCs acquire the senescent phenotype and irreversible growth arrest demonstrated by the in vivo expression of the associated protein p16INK4a. Consequently, cardiac aging is associated with the formation of dysfunctional niches where an imbalance between dividing and senescent CPCs is observed, ultimately altering both tissue and organ homeostasis (77). Moreover, aging has been reported to influence tissue oxygenation by unbalancing the ratio between hypoxia (required for long-term preservation of undifferentiated CPCs) and normoxia (required for active cardiomyogenesis typical of young CPCs), thus exacerbating the accumulation of fibroblasts in hypoxic foci and increased plasma levels of the advanced glycated end product N'-carboxymethyl lysine (CML) (78).

Cardiac progenitor cells nested in this unbalanced and unfavorable microenvironment, are not able to re-enter the cell cycle (77). The decrease in tissue homeostasis results in the accumulation of senescent cardiomyocytes, thus compromising ventricular contractile function. In addition, aging negatively acts on CPC survival and migration, although the effect on growth is controversial $(31,35,36)$. Confirmatory clinical studies have highlighted the poor efficiency in proliferation and differentiation of CPCs isolated from older donors compared to younger donors. Accordingly, the administration of old versus young cells in an animal model of MI, was associated with a reduced therapeutic potential of the treatment (33).

From a molecular standpoint, three main receptors appear to be involved in CPC senescence and the development of myocardial aging: IGF-1/IGF-1R, HGF-C-Met and the rennin angiotensin system (RAS). In the heart, activation of IGF-1/IGF-1R signaling is associated with CPC division, increased telomerase activity, prevention of replicative senescence and consequent better maintenance of the CPC pool (79-81). The expression of IGF-1R and IGF-1 synthesis are attenuated in the aged CPCs, negatively impacting telomere length and oxidative damage susceptibility (82). Indeed, IGF-1 is able to interfere with ROS generation and has been shown to decrease oxidative damage in the aging myocardium (77). ROS generation and accumulation of oxidative DNA damage in aged CPCs is associated with Ang II production (83) followed by the shortening and uncapping of telomeres (84). Aging also decreases Hepatocyte Growth Factor HGF production mainly affecting CPC migration ability, (in terms of the numbers and speed of CPC migration), by modulating their ability to move towards the damaged area and to promote heart regeneration $(83,85,86)$. Despite this, BrdU incorporation experiments performed in the apex and atrium of senescent hearts revealed the presence of functionally competent CPCs which are responsive to growth factors and have preserved telomeres and are partially capable of reverting aging myopathy (83). 
The influence of aging on stem cell function has also been reported in stem cell populations of non-cardiac-origin such as in A-MSCs. Aging affects the multilineage differentiation potential of A-MSCs as well as their proliferation capacity, cellular senescence and ability to produce paracrine factors. It has been shown that A-MSCs from aged patients have increased telomere shortening, decreased ability to stimulate the production of capillary-like tubes by endothelial cells and decreased secretion of pro-angiogenic factors such as VEGF, PGF, HGF, angiopoetin-1 and angiogenin. Furthermore, aging has been also associated with the abnormal expression of DNA damage repair genes and increased CHEK1 and p16INK4a which are involved in senescence $(87,88)$. Similarly, aging leads to a functional impairment of BM-MSCs, as shown by the limited ability to secrete angiogenic factors, reduced regenerative potential (88) and by the inability to induce neo-angiogenesis after MI (89). Moreover, cells from old patients exhibit reduced tolerance to ischemia, in terms of survival in ischemic muscle, compared to young patients (90).

Moreover, aging can impact the mobilization capacity of BM cells after acute myocardial infarction (AMI) in humans (91) resulting in a decreased number of CD $34^{+}$cells in peripheral blood (92). Preclinical studies analyzing the angiogenic response of young cells in the aged heart, showed that the aged heart is rejuvenated when cardiac endogenous BM cells are replaced with young BM cells in a model of parabiosis (93). Telomere shortening and replicative exhaustion has also been observed in aged HSC populations (83, 94). HSCs display impaired migration and lineage commitment potential with decreased hematopoiesis and lymphopoiesis (83, 95-97). In particular, a similar impairment in CPC and HSC migration in response to specific stimuli, such as stromal derived factor (SDF-1) and VEGF $(83,97)$ has been observed. Aging has been associated with a reduction in the number and function of circulating EPCs (98). Furthermore, only EPCs from young patients are incorporated into the neovascolature and are able to restore angiogenic functions in the heart (99).

In conclusion, these observations clearly demonstrate that aging represents a critical factor influencing the regenerative potential of adult stem cells and therefore their possible use in cardiac regenerative medicine.

\subsection{Metabolic syndrome}

Metabolic syndrome includes several diseases such as insulin resistance, impaired glucose tolerance, type 2 diabetes, dyslipidemia, obesity, high blood pressure dyslipidemia, microalbuminuria, which are all associated with an increased risk of coronary artery disease (CAD) linked to aging $(7,100)$. Patients with metabolic syndrome are 3-4 times more likely to develop type II diabetes and the risk of developing cardiovascular disease is almost tripled (101). Mansilla et al., firstly proposed metabolic syndrome as an exhaustive syndrome of the stem cell pool, where defects in specific biological mechanisms of stem cells are strictly linked to the progression of the syndrome itself (102). In fact, the persistent inflammatory state (increased levels of IFN- $\alpha, \mathrm{IL}-6$ ) developed in metabolic syndrome leads to the continuous recruitment of the stem cell pool from their tissue of origin, thus causing pool exhaustion (102). Specifically, several evidences have highlighted a correlation between increased oxidative stress, telomere shortening and reduced function of circulating EPCs (103). Accordingly, a low percentage of circulating EPCs $(40 \%$ less than controls without metabolic syndrome) was found in healthy men with abdominal obesity and metabolic syndrome (101). The decrease in the endogenous EPC pool observed in metabolic syndrome seems to accelerate the development of cardiovascular disease (102).

Metabolic syndrome also negatively impacts CPC activity and regenerative ability (104-106). One possible mechanism is related to the deregulation of intracellular $\mathrm{Ca}^{2+}$ levels due to the downregulation of Inositol 1,4,5-trisphosphate receptors (IP3Rs) and the sarco/endoplasmic reticulum $\mathrm{Ca}^{2+}$-ATPase (SERCA) which in turn influences both CPC proliferation and the overall regenerative capacity of the myocardium (107).

Among all conditions that contribute to the development of metabolic syndrome, type 2 diabetes is the most frequent. Interestingly, diabetic cardiomyopathy has been proposed as a CPC disease whose abnormalities lead to an imbalance between cell death and tissue regeneration (104). Noteworthy, cell death of mature cardiomyocytes, SMCs and ECs represent only a secondary phenomenon since CPC exhaustion precedes the progression of diabetic myopathy (104). Indeed, the metabolic pathways supporting CPC function has been reported only very recently. Salabei et al. have shown that murine CPCs expressing high levels of the glucose transporter Glut-1 largely depend on the extracellular glucose concentration for their glycolytic rate, thus suggesting that CPCs could be prone to hyperglycemic injury (40). Another protein playing an important role in diabetic myopathy is the p66shc protein, lack-of-which has beneficial effects on both viability and function of CPCs, and enhances cardiomyocyte differentiation (104). Hyperglycemia is also linked to O-glycosylation of proteins, including the activation of p53 which is able to up-regulate the renin-angiotensin system, conducive to the synthesis of angiotensin II (Ang II), resulting in increased cytosolic calcium-induced generation of reactive oxygen species (ROS) and apoptosis (108). ROS formation initiates DNA damage, telomere shortening, irreversible growth arrest and cell senescence (84). The impairment of the CPC pool in the heart due to hyperglycemia ultimately leads 
to the accumulation of old and dying cardiomyocytes with consequent clinically relevant defects in contraction. Moreover decreased muscle mass and dilation of the heart chambers contributes to ventricular function deficits (104).

The relation between glucose and cardiac metabolism is extremely relevant. In the cardiac tissue, glucose metabolism plays a key role both in physiological and pathological conditions (109). For instance, the pentose phosphate pathway, is important for maintaining contractility and the redox state of cardiomyocytes, generating NAPDH which in turn acts as an alternative substrate to anabolic glycolysis. Importantly, CPCs isolated from hearts of diabetic mice followed by culture in high glucose media, display reduced activity in key enzymes of the pentose phosphate pathway (glucose-6phosphate dehydrogenase (G6PD) and trans-ketolase) resulting in the accumulation of glucose-induced Advanced Glycation End-products (AGEs), inhibition of pro-survival pathway Akt/Pim-1/Bcl-2 and activation of apoptosis (110). Similar phenomena also occur in CPCs isolated from diabetic hearts reconditioned with physiologically normal glucose levels, confirming the concept of the existence of a metabolic memory as a consequence of previous exposures to high levels of glucose (110). In human diabetic hearts, the number of CPCs is reduced also showing less proliferative and regenerative capacity compared to non-diabetic patients $(110,111)$. Cells derived from diabetic patients and cells preconditioned with high glucose exhibit reduced pro-angiogenic capacity that is restored following treatment with glyoxalase-1, suggesting that the defect can be linked to the accumulation of reactive dicarbonyls (111). Comparative studies have also shown that CSCs cultured in high glucose concentrations are still able to improve heart function in terms of LVEF but to a lesser degree than CSCs grown in normoglycemic medium (111).

Similar observations have also been reported in cardiac derived MSCs (C-MSCs). In a rat model of chronic myocardial infarction, C-MSCs have been shown to contribute to cardiac repair and display better persistence, migration and differentiation properties as compared to BM cells isolated from the same patients (112). Interestingly, C-MSCs derived from patients with diabetes Mellitus (DM C-MSCs) have shown a reduced rate of proliferation, premature senescence (identified by the positive staining for beta-galactosidase and increased p21wa61 protein expression, respectively). Furthermore, diabetic C-MSCs display a decreased ability to differentiate along adipogenic, endothelial and cardiac lineages when compared to C-MSCs isolated from normoglycemic patients (113).

Long-term defects in type 2 diabetes have also been associated with damage in A-MSC function.
Cramer et al. have shown that high levels of glucose reduce the proliferative capacity of A-MSCs isolated both from diabetic (dA-MSCs) and non-diabetic (nA-MSCs) donors, however the influence was more significant in dA-MSCs. This phenomenon seems to be reversible only in nA-MSCs, where there is an increase in proliferative capacity after insulin treatment, unlike the dA-MSCs that instead showed increased senescence and apoptosis. Furthermore, elevated glucose levels influence A-MSC differentiation, reducing the osteogenic and chondrogenic potential and increasing the adipogenic commitment (114).

A similar scenario has been demonstrated in other stem cell types. For instance, both type 1 and type 2 diabetes are associated with reduced levels (mean reduction of $40 \%$ ) and poor functioning circulating EPCs (115-117). The number of EPCs inversely correlates with glycated hemoglobin (HbA1c) levels (118-120) and with fasting glucose levels. In particular, a decreased number of CD34 ${ }^{+} / \mathrm{KDR}$ EPCs have been reported to inversely correlate with the severity of diabetic vasculopathy (121). EPCs from patients with type 2 diabetes mellitus (DM), have shown impaired proliferation (important for amplifying the pool of endothelial cells), tubulization (necessary to create new vascular structures), adhesion to activated endothelium (critical for the recruitment of circulating EPCs to the site of interest) and migration toward cytokine gradients (such as G-CSF). Interestingly, these defects are not reverted by normoglycemic cell culture conditions $(122,123)$. However DM does not impact different properties of EPCs such as adherence to fibronectin, collagen and quiescent endothelial cells $(67,116)$. More importantly, the hyperglycemic-induced alterations in EPC function are mediated by pathophysiological mechanisms such as inflammation, oxidative stress, altered Akt pathway signaling and nitric oxide (NO) have been reported on multiple levels: mobilization from BM, trafficking and survival in the circulation, homing and neovascularization (67). From a molecular standpoint, a possible explanation of EPC defects could be the activation of MAP kinases, such as p38 that decrease the proliferation and differentiation capacity of EPCs in culture (124), increasing EPC senescence and apoptosis. In DM, increased levels of SDF-1 in the BM (due to increased CD26/DPP-4) and decreased SDF-1 production in the ischemic tissue is conducive to a decrease in the SDF-1 gradient which is normally responsible of mobilizing EPCs from the BM into the circulation (125-127). It has been shown that the longterm in vitro exposure to high glucose concentrations, inhibits the proliferative capacity, EPC migration and the capability of colony formation $(128,129)$. In these conditions a decrease in $\mathrm{NO}$ and vascular endothelial growth factor (VEGF) secretion in combination with a reduction in the activity of superoxide dismutase (SOD) have been found. Therefore, it is clear that the 
defects observed in diabetic EPCs are certainly due to the toxic effects of high glucose. However, strict glucose control in DM patients had no significant effect on the rates of major cardiovascular events, death, or microvascular complications (130-132). When used in animal models of ischemia, diabetic-EPCs were less effective in restoring blood flow compared to cells derived from healthy controls (124). In addition, in diabetic mice, injection of BM-MNCs from healthy controls was more effective than BM-MNCs from diabetic patients. As observed in EPCs, BM-MNC dysfunction has been associated with an in vitro impairment of differentiation capacity and in vivo defects in the formation of vascularlike structures in Matrigel ${ }^{\circledR}$ plug experiments (133). Moreover diabetic BM-MNCs are not able to improve cardiac function following injection into a mouse model of MI unlike control BM-MNCs (134).

\section{STRATEGIES TO ENHANCE STEM CELL REGENERATIVE POTENTIAL}

The literature reviewed in the previous sections clearly indicate that factors such as age, metabolic syndrome and diabetes negatively influence the regenerative capacity of stem and progenitor cells used for cell therapy. The development of innovative approaches to improve the engraftment and regenerative potential of stem cells is a critical challenge for the successful employment of cell therapy in the cardiovascular context. To remedy this, three main strategies have been proposed: 1) the development of treatments to restore or to improve the function of 'sick' cells before their reinfusion in the damaged heart, 2) the preparation of the recipient tissue by treating the patient with drugs able to increase the engraftment of transplanted cells, 3) the infusion of allogeneic rather than autologous cells.

\subsection{Pretreating stem cells before their reinfusion}

The rationale of this approach consists the activation or enhancement of specific molecular pathways able to improve the response of stem cell progenitors to stress or enhance their regenerative abilities following the in vivo injection in the damaged tissue. Stem cells are commonly treated after their isolation, during in vitro expansion and before their injection into the site of injury. In this section we will review some of the most representative examples of cell pretreatment-based protocols that are currently employed including: growth factors, drugs, viral transduction and tissue engineering based approaches.

Statins are drugs that inhibit the synthesis of endogenous cholesterol by acting on the hydroxylmethylglutaryl CoA-reductase. Several studies have suggested that statins benefit patients with ischemic and non-ischemic cardiomyopathies (135). Statins exert pleiotropic effects with different outcomes depending on the target cell, the type of statin, and the concentration and timing of treatment. Most of the studies regarding the effect of statins on stem cell biology have been performed on EPCs and MSCs. Systemic administration of statins has been shown to normalize EPC levels, restore their endothelial regenerative capacity and reduce the cardiovascular risk in subjects with metabolic syndrome (101). Statins increase the bioavailability of $\mathrm{NO}$ and reduce EPC apoptosis and oxidative stress (136). Moreover, statin treatment delays EPC aging by increasing the expression and activity of the telomere-capping protein TRF2 and cell cycle cyclins, and decreases the cell cycle inhibitor p27Kip1 $(137,138)$.

Another treatment able to improve EPC function is represented by the administration of growth factors. Insulin growth factor 1 (IGF-1) increases the number of circulating EPCs, enhancing their colony formation ability, migratory capacity and the incorporation into tubular-like structures (139). Notably, either alone or in combination with hepatocyte growth factor (HGF), the IGF-1 treatment has been also proven to induce a beneficial effect, by acting on CPC division and differentiation after injection in a rat model of MI (83). Similarly, when administrated systemically, stem cell factor (SCF) has been shown to partially activate CPCs in situ reversing myocardial aging in mice (77). Additionally the administration of Placenta Growth Factor (PIGF) has been shown to increase the in vivo mobilization and recruitment of $B M$ derived stem cells in a diabetic murine model of hindlimb ischemia. PIGF also improves EPC differentiation both in vitro and in vivo, increasing neovascularization and blood flow recovery in treated versus untreated diabetic mice (133). The decrease of endothelial nitric oxide synthase (eNOS) observed in diabetic EPCs has been shown to be rescued by hyperoxia treatment, or by SDF-1 administration, which is able to increase the neovascularization and wound healing in animal models $(70,140)$. Insulin in diabetic patients can increase the number of circulating EPCs, to boost their in vitro growth and angiogenic potential, VEGF production and mobilization (125). This effect is enhanced in the presence of the SDF-1 3'-A/G allele, a polymorphism in SDF-1 gene associated with increased EPC mobilization (141).

A possible alternative to growth factors is represented by the use of drugs, reported as particularly beneficial to 'correct' the detrimental influence that metabolic syndrome and/or diabetes have on stem cell function. Benfotiamine (BFT), a synthetic S-acyl derivative of thiamine (vitamin B1), has been shown to reactivate the pentose phosphate pathway, which is reduced in the diabetic context, restoring the function of CPCs in the heart (110). Similarly, the histone acetylase (HAT) activator pentadecylidenemalonate 1b (SPV106), has been shown to help the function of diabetic C-MSC, improving their proliferation, differentiation capacity and histone modifications which are compromised in patients 
with type 2 diabetes (113). Methylglyoxal (MG), that is a reduced derivative of pyruvic acid, accumulates in diabetes and impairs neovascularization. The overexpression of MG-metabolizing enzyme glyoxalase-1 (GLO1), is able to revert the detrimental effects of diabetes in BM-cells (142) and CPCs (111), restoring their proangiogenic capacity. Other drugs can act by amplifying the number and function of EPCs in type II diabetes; Angiotensin II type 1 Receptor Blockers ARBs increase the number of EPCs (143); agonists of PPAR- $\gamma$ act through the PI3K/Akt pathway (144); the thiazolidinediones activate the Akt/ eNOS pathway; ephrin-B2/Fc (145), and DDP-4 inhibition augments the in vitro number (146), migration capability and regenerative capacity of EPCs $(147,148)$; whereas G-CSF (149), erythropoietin (150), estrogen (151) and VEGF (152) act as mobilizing agents (153). Hydrogen sulfide, is able to enhance wound healing in type II diabetes patients by restoring EPC function and increasing the levels of angiopoietin-1 (154).

Different strategies based on genetic or molecular modifications of stem cells have also been proposed. For instance, the inhibition of p38-kinase by SB203580 (a pyridinyl imidazole inhibitor of p38-kinase) or by infection with a dominant negative p38-kinase adenovirus or adiponectin (155) is able to act on EPC proliferation and differentiation in diabetes. Indeed, inhibition of p38 promotes the differentiation of EPCs to the endothelial lineage rather than the monocytemacrophage lineage and it increases VEGF levels which is largely demonstrated to play a key role in angiogenesis $(70,124)$. Alternatively, the molecular regulation of EPC function, which is physiologically compromised in diabetic patients, may reside in the regulation of miRNA 126 and 130a, normally altered in diabetes $(156,157)$ and recently proposed as a novel therapeutic target.

Interestingly, the strategy of pretreating stem cells with drugs to improve stem cell regenerative potential has also been successfully assessed in A-MSCs. Natural agents such as curcumin, extracted from the spice turmeric has been reported to exhibit antioxidant and anti-inflammatory properties (158, 159). In a rat model of myocardial ischemia-reperfusion injury (IRI), transplantation of curcumin pretreated A-MSCs not only improves heart function, higher cell retention, smaller infarct size, but also decreases myocardial apoptosis and promotes neovascularization and increased VEGF levels in the peri-infarcted area (160).

Finally, a triple approach based on the combination of tissue engineering, stem cells and drugs is now under clinical evaluation, such as the use of scaffolds to enhance stem cell engraftment. A-MSCs embedded in a scaffold of platelet-rich fibrin (PRF) have been shown to significantly promote angiogenesis, to preserve wall thickness and heart function, as well as to reduce infarct size, LV chamber size, and LV remodeling (161). Similarly, the use of alginate hydrogels has been demonstrated to augment the retention of A-MSCs after their injection in patients with ischemic heart disease without affecting their paracrine potential (162). The use of A-MSCs conjugated with VEGF-releasing poly lacticco-glycolic acid (PLGA) and pharmacologically active microcarriers (PAMs) has resulted in their increased proliferation, angiogenic differentiation and VEGF production, as well as in decreased cell death compared to unconjugated A-MSCs. Similarly, A-MSCs conjugated with VEGF-releasing PAMs could have therapeutic applications in treating patients with vascular disease, including those with a previous AMI (163). In fact, in a murine model of AMI, the transplantation of A-MSCs conjugated with VEGF-releasing PAMs into the ischemic region has already been shown to improve post-AMI cardiac function and to increase arteriogenesis. Lastly, a significant improvement of the efficacy of stem cell regenerative activity has also been demonstrated using hydrogels suitably modified, in order to allow the controlled release of NO by MSCs, thus enhancing their therapeutic efficacy in the treatment of MI (164).

\subsection{Treatment of target tissue: how to rejuvenate cardiac tissue}

As already discussed, aging and metabolic dysfunctions have a detrimental effect not only on stem cells but also on tissue function, highlighting the critical role of the cardiac microenvironment in the recipient. The biological and molecular alterations within a hostile microenvironment such as that produced after a cardiac insult, may certainly influence the proliferative capacity of stem cells once injected $(70,162,163)$. Therefore, a key question currently under clinical evaluation is the possibility to rejuvenate the target tissue (68). Accordingly, changing the microenvironment of the injection site may be useful to increase the engraftment of transplanted cells, but also their regenerative capacity has been targeted. It has been demonstrated in a model of hetero-chronic parabiosis, that circulating factors can "rejuvenate" hMSCs in the old parabiont (71). Specifically, the factors that seem to hold rejuvenating properties on aged hMSCs are linked to the circulating growth differentiation factors (71), including members of the transforming growth factor beta superfamily (VEGF and bFGF; 72, 73). These effects have been demonstrated both in vitro and in vivo after MI. To date a variety of factors delivered to the site of cell therapy injection locations have been exploited. Local injection of HMGB-1 increases the regeneration of infarcted myocardium by activating endogenous CSCs $(165,166)$. Transplantation of syngeneic cardiac fibroblasts stably overexpressing SDF-1, increases the homing of c-kit ${ }^{+}$ cells into the myocardium, which has also been shown to generate a stabilized SDF-1 mutant $(167,168)$. The overexpression of IGF-1 restricted to myocytes retards both aging of CPCs and myocytes, and the onset of 
ventricular dysfunction (80). It has been demonstrated that age-dependent impairment of EPCs is corrected by growth-hormone-mediated IGF-1 increase, both in a preclinical animal model and in humans (139). Moreover, the delivery of IGF-1 injected locally into the myocardium through biotinylated peptide nanofibers, improves neonatal rat cardiomyocyte cell therapy after MI (81). The administration of PDGF, which is downregulated during aging, is able to reverse the senescent predisposition to increased cardiac injury (169). Other biological candidates have been recently discovered. For instance, the circulating extracellular domain of Klotho, a transmembrane protein that controls the sensitivity of cells to insulin which plays a main role in aging, has been postulated to act as an anti-aging hormone $(170,171)$. The overexpression of Klotho in mice extends lifespan (170) not by simply acting on insulin/IGF-1 signaling, but also by increasing oxidative stress resistance via the the upregulation of manganese superoxide dismutase and also acting as an essential cofactor of fibroblast growth factor signaling (172). Additionally, Klotho can influence the regenerative response of tissue-resident stem cells in multiple organs involving a more complex scenario. Finally, a novel rejuvenating approach consists lowenergy shock wave-induced tissue activation which stimulated the expression of SDF-1 and VEGF in the target tissue and promoted homing of intravenously infused EPCs in uninjured and chronically ischemic rats (173).

\section{ALTERNATIVES TO AUTOLOGOUS CELL THERAPY}

So far, cell therapy (not only in the cardiovascular field), has been mainly based on the employment of autologous stem cells, treated to enhance their potency or commitment in order to replace or regenerate the damaged tissue. Given the role of aging in recipients (69), the host environment plays an even more relevant role in the clinical outcome of the cell regenerative response to the ischemic injury.

Over the years autologous cell therapies have shown several limitations. The proliferative and regenerative capacity of progenitor cells decreases with age $(174,175)$, with a consistent reduced efficacy of progenitor cells from old patients. Another practical limitation consists in the collection of BM samples or biopsies from other sources that often require invasive procedures. As the low percentage of stem and progenitor cells in the starting material might occur, cells need to be expanded ex vivo before autologous applications. Such procedures may require days (176) or weeks (177), depending on the cell number needed and the age and comorbidities of the donor, as progenitor cells from old patients have reduced proliferation potential $(90,174,175)$. To date, stem cell ex vivo expansion requires Good Manufacturing Practice (GMP) compliant facilities. Although safety and reproducibility is assured within cell factories, however, patient-specific tissue harvesting and cell preconditioning may result in a delayed start of the therapy, with a risk of the introduction of possible variations in cell potency related to patient age and disease $(68,178,179)$.

One possibility to improve the efficacy of stem cell therapy is represented by the use of allogeneic cells. Allogeneic cell therapy from young donors have several advantages over autologous, including a higher regenerative potential (180) and availability for clinical use at any time. Moreover, cells from a single donor can be used for many patients, thus tremendously reducing the manufacturing costs of cell products. In this scenario, we could hypothesize the employment of young cells in aged patients or healthy cells in patients with metabolic diseases (such as diabetes or metabolic syndrome) to overcome the decreased activity of the respective autologous cells.

Allogeneic CDC transplantation without concomitant immunosuppression has been demonstrated to be safe $(181,182)$ and promotes cardiac regeneration, improving heart function and endogenous repair mechanisms in a rat MI model (178). CDCs have a low immunomodulatory profile and their allogeneic transplantation only induces a transient mild local immune reaction in a rat $\mathrm{MI}$ model. The biological and functional benefits of such a strategy, almost indistinguishable from syngeneic transplantation, could persist 6 months post-MI (178).

In addition, MSCs have been shown to inhibit T-cell responses through the modulation of $B$ cells and antigen-presenting cells (183-185), to induce a local immunosuppressive environment through the production of prostaglandins and antiinflammatory cytokines $(186,187)$, and to inhibit lymphocyte proliferation, dendritic cell maturation and alloimmune rejection $(186,188-193)$. Due to their immunomodulatory properties, MSCs have been tested in initial clinical studies of graft versus-host diseases (194), osteogenesis imperfecta (195), glycogen storage diseases (196), Crohn's disease (197) and organ transplantation $(26,27,198)$. In fact, adult human MSCs express intermediate levels of MHC-I but do not express human leukocyte antigen (HLA) class II (16) or co-stimulatory molecules on the cell surface under normal in vitro conditions. However, HLA-II has been detected in lysates of unstimulated MSCs, presumably reflecting intracellular deposits of the antigen. Treatment with interferon- $\gamma$ has been found to induce the expression of HLA class II on the cell surface (189). Another study has shown that MSCs express MHC-II as antigen presenting cells in presence of low levels of interferon- $\gamma$, whereas high levels of interferon- $\gamma$ impair its expression (199). 
Despite this, the potential immunogenicity of allogeneic MSCs remains an unresolved issue that may affect their clinical efficacy. In fact, it has been shown that although MSCs actively inhibit rejection (200), they might be immune-rejected upon cardiac differentiation in the injured heart (201). Again, both allogeneic MSCs and autologous cells have been shown to improve cardiac function 1 month after $\mathrm{MI}$ in a rat MI model (201). However, 6 months after infarction, the allogeneic MSCs were rejected, resulting in decreased heart function. If MSCs were in vivo pretreated with prostaglandin E2, allogeneic injection of MSCs still prevents rejection and ventricular function could be restored, thus highlighting the importance of the immune/inflammatory system in balancing cardiac repair (202).

The first Phase I, randomized, double-blinded, placebo-controlled, dose escalation clinical study (181), has demonstrated that delivery of MSCs is safe and elicits no allogeneic T-cell response. This trial has evaluated the effect of cell dosage, also showing that higher doses of stem cells may not always provide greater benefit (203 205). Authors have postulated that the biological effect of stem cell injection likely reaches a plateau, as lower cell doses have been found to display greater improvements in heart function, whereas higher cell concentrations could result in improved inflammatory responses, thus affecting cell performance (203). The POSEIDON trial has randomized 30 patients with heart failure to receive either allogeneic or autologous mesenchymal stem cells (MSCs) by direct endomyocardial injection. Several studies have shown delayed host responses to allogeneic MSCs in vivo around 2 weeks after transplantation, suggesting that tolerance of MSCs across the allogeneic barrier may not be absolute $(201,206-208)$. Moreover, the trans-differentiation of MSCs into cardiac lineage cells in response to 5-azacytidine or cytokine treatment increased the expression of immunostimulatory MHC-la and MHC-II molecules and decreases the immunomodulatory $\mathrm{MHC}-\mathrm{ll} \mathrm{b}$, resulting in enhanced cytotoxicity of MSCs in co-culture with allogeneic leukocytes (201). These observations suggest that MSCs can switch their immune states from immunomodulatory to immunostimulatory depending on the biological context (201).

\section{CONCLUSIONS AND FUTURE PERSPECTIVES}

It is hard to predict whether or not stem cellbased therapies will represent a clinically reliable therapeutic strategy to fully restore cardiac function., The impact of diseases such as metabolic syndrome, diabetes and aging on endogenous stem/progenitor cells and on cardiac microenvironment may limit the benefits of cell therapy.
So far, cell-based therapy has been extensively studied in animal models, using the abovementioned cell populations. Most of the clinical trials have only tested the safety and efficacy of autologous adult stem cells. A progressive research approach in preclinical and clinical studies is needed to ensure the realization of cardiac regeneration by allogeneic cell therapy. The allogeneic scenario may offer the advantage of collecting young and healthy "universal donor cells" (209), and to expand the cells in advance in dedicated and controlled GMP-facilities. This would allow the potential to obtain an unlimited number of doses for clinical administration and even to treat acute diseases such as MI. Additionally, the employment of a specific stem cell population showing low immunogenic properties would avoid the use of immunosuppressive treatment. To date, several issues remain unresolved. Experimental evidence suggest that even in vivo allogeneic transplanted MSCs may switch to different immune states, inducing alloimmune rejection (201). Therefore, minimizing donor-recipient HLA-II mismatch might represent a good strategy in order to attenuate alloimmune rejection of transplanted MSCs. In line with this, very promising studies are focusing on the establishment of a GMP HLA homozygous haplobanks which should overcome the issue of HLA mismatch in the context of cell-based transplants (210).

In addition, the low retention and engraftment of stem cells within damaged cardiac tissue after clinical administration requires a better definition of the biological mechanisms underlying such processes. Nevertheless, given the key role of stem cell paracrine action as a major mechanism involved in immune rejection after in vivo injection, a long-term survival of transplanted stem cells may not be necessary to achieve long-lasting clinical effects (211). In the future the "off the shelf" cell therapy product could become a reality, by developing human pluripotent stem cell bio-banks with low immunogenic properties and high regenerative capacity (212).

\section{ACKNOWLEDGEMENTS}

This work was supported by FP7-PEOPLE2011-(CIG, N.294176) to Daniele Avitabile, Centro Cardiologico Monzino IRCCS, RC 2014/15. Authors express no conflict of interest. We thank Dr. Aoife Gowran for her assistance in English proofreading.

\section{REFERENCES}

1. D Mozaffarian, EJ Benjamin, AS Go, DK Arnett, MJ Blaha, M Cushman, S de Ferranti, JP Despres, HJ Fullerton, VJ Howard, MD Huffman, SE Judd, BM Kissela, DT Lackland, JH Lichtman, LD Lisabeth, S Liu, RH Mackey, DB Matchar, DK McGuire, ER Mohler, $3^{\text {rd }}$, CS Moy, P Muntner, ME Mussolino, K Nasir, RW 
Neumar, G Nichol, L Palaniappan, DK Pandey, MJ Reeves, CJ Rodriguez, PD Sorlie, J Stein, A Towfighi, TN Turan, SS Virani, JZ Willey, D Woo, RW Yeh, MB Turner: Heart disease and stroke statistics--2015 update: a report from the American Heart Association. Circulation 131, e29-322 (2015)

DOI: $10.1161 / C I R .0000000000000152$

2. G Biondi-Zoccai, E De Falco, M Peruzzi, E Cavarretta, M Mancone, O Leoni, ME Caristo, M Lotrionte, AG Marullo, A Amodeo, L Pacini, A Calogero, V Petrozza, I Chimenti, F D'Ascenzo, G Frati: A novel closed-chest porcine model of chronic ischemic heart failure suitable for experimental research in cardiovascular disease. Biomed Res Int 2013, 410631 (2013)

DOI: $10.1155 / 2013 / 410631$

3. $X$ Wang, J Zhang, $F$ Zhang, J Li, Y Li, Z Tan, J Hu, Y Qi, Q Li, B Yan: The Clinical Status of Stem Cell Therapy for Ischemic Cardiomyopathy. Stem Cells Int 2015, 135023 (2015)

DOI: $10.1155 / 2015 / 135023$

4. K Ito, T Suda: Metabolic requirements for the maintenance of self-renewing stem cells. Nat Rev Mol Cell Biol 15, 243-256 (2014) DOI: 10.1038/nrm3772

5. AP Beltrami, L Barlucchi, D Torella, M Baker, F Limana, S Chimenti, H Kasahara, M Rota, E Musso, K Urbanek, A Leri, J Kajstura, B Nadal-Ginard, P Anversa: Adult cardiac stem cells are multipotent and support myocardial regeneration. Cell 114, 763-776 (2003)

DOI: 10.1016/S0092-8674(03)00687-1

6. K Urbanek, M Rota, S Cascapera, C Bearzi, A Nascimbene, A De Angelis, T Hosoda, S Chimenti, M Baker, F Limana, D Nurzynska, D Torella, F Rotatori, R Rastaldo, E Musso, F Quaini, A Leri, J Kajstura, P Anversa: Cardiac stem cells possess growth factor-receptor systems that after activation regenerate the infarcted myocardium, improving ventricular function and long-term survival. Circ Res 97, 663-673 (2005)

DOI: 10.1161/01.RES.0000183733.53101.11

7. H Oh, SB Bradfute, TD Gallardo, T Nakamura, V Gaussin, Y Mishina, J Pocius, LH Michael, RR Behringer, DJ Garry, ML Entman, MD Schneider: Cardiac progenitor cells from adult myocardium: homing, differentiation, and fusion after infarction. Proc Natl Acad Sci U S A 100, 12313-12318 (2003)

DOI: 10.1073/pnas.2132126100

8. B Dawn, AB Stein, K Urbanek, M Rota, B Whang, R Rastaldo, D Torella, XL Tang, A Rezazadeh, J Kajstura, A Leri, G Hunt, J Varma, SD Prabhu, P Anversa, R Bolli: Cardiac stem cells delivered intravascularly traverse the vessel barrier, regenerate infarcted myocardium, and improve cardiac function. Proc Natl Acad Sci U S A 102, 3766-3771 (2005)

DOI: $10.1073 /$ pnas.0405957102

9. C Bearzi, M Rota, T Hosoda, J Tillmanns, A Nascimbene, A De Angelis, S YasuzawaAmano, I Trofimova, RW Siggins, N Lecapitaine, S Cascapera, AP Beltrami, DA D'Alessandro, E Zias, F Quaini, K Urbanek, RE Michler, R Bolli, J Kajstura, A Leri, P Anversa: Human cardiac stem cells. Proc Natl Acad Sci U S A 104, 14068-14073 (2007) DOI: 10.1073/pnas.0706760104

10. E Gambini, G Pompilio, A Biondi, F Alamanni, MC Capogrossi, M Agrifoglio, M Pesce: C-kit+ cardiac progenitors exhibit mesenchymal markers and preferential cardiovascular commitment. Cardiovasc Res 89, 362-373 (2011)

DOI: $10.1093 / c v r / c v q 292$

11. A Magenta, D Avitabile, G Pompilio, MC Capogrossi: c-kit-Positive cardiac progenitor cells: the heart of stemness. Circ Res 112, 1202-1204 (2013)

DOI: 10.1161/CIRCRESAHA.113.301317

12. TS Li, K Cheng, ST Lee, S Matsushita, D Davis, K Malliaras, Y Zhang, N Matsushita, RR Smith, E Marban: Cardiospheres recapitulate a niche-like microenvironment rich in stemness and cell-matrix interactions, rationalizing their enhanced functional potency for myocardial repair. Stem Cells 28, 2088-2098 (2010)

DOI: 10.1002/stem.532

13. R Bolli, AR Chugh, D D'Amario, JH Loughran, MF Stoddard, S Ikram, GM Beache, SG Wagner, A Leri, T Hosoda, F Sanada, JB Elmore, P Goichberg, D Cappetta, NK Solankhi, I Fahsah, DG Rokosh, MS Slaughter, J Kajstura, P Anversa: Cardiac stem cells in patients with ischaemic cardiomyopathy (SCIPIO): initial results of a randomised phase 1 trial. Lancet 378, 1847-1857 (2011) 
DOI: 10.1016/S0140-6736(11)61590-0

14. AR Chugh, GM Beache, JH Loughran, N Mewton, JB Elmore, J Kajstura, P Pappas, A Tatooles, MF Stoddard, JA Lima, MS Slaughter, P Anversa, R Bolli: Administration of cardiac stem cells in patients with ischemic cardiomyopathy: the SCIPIO trial: surgical aspects and interim analysis of myocardial function and viability by magnetic resonance. Circulation 126, S54-64 (2012)

DOI: $\quad$ 10.1161/CIRCULATIONAHA.112. 092627

15. K Malliaras, RR Makkar, RR Smith, K Cheng, E Wu, RO Bonow, L Marban, A Mendizabal, E Cingolani, PV Johnston, G Gerstenblith, KH Schuleri, AC Lardo, E Marban: Intracoronary cardiosphere-derived cells after myocardial infarction: evidence of therapeutic regeneration in the final 1-year results of the CADUCEUS trial (CArdiosphere-Derived aUtologous stem CElls to reverse ventricUlar dySfunction). J Am Coll Cardiol 63, 110-122 (2014)

DOI: 10.1016/j.jacc.2013.08.724

16. SJ Joggerst, AK Hatzopoulos: Stem cell therapy for cardiac repair: benefits and barriers. Expert Rev Mol Med 11, e20 (2009) DOI: 10.1017/S1462399409001124

17. D Bongiovanni, B Bassetti, E Gambini, G Gaipa, G Frati, F Achilli, P Scacciatella, C Carbucicchio, G Pompilio: The CD133+ cell as advanced medicinal product for myocardial and limb ischemia. Stem Cells Dev 23, 2403-2421 (2014)

DOI: 10.1089/scd.2014.0111

18. JM Hill, G Zalos, JP Halcox, WH Schenke, MA Waclawiw, AA Quyyumi, T Finkel: Circulating endothelial progenitor cells, vascular function, and cardiovascular risk. N Engl J Med 348, 593-600 (2003)

DOI: 10.1056/NEJMoa022287

19. $\mathrm{Y} \mathrm{Hu}, \mathrm{F}$ Davison, $\mathrm{Z}$ Zhang, $\mathrm{Q} \mathrm{Xu}$ : Endothelial replacement and angiogenesis in arteriosclerotic lesions of allografts are contributed by circulating progenitor cells. Circulation 108, 3122-3127 (2003)

DOI: 10.1161/01.CIR.0000105722.96112.67

20. V Schachinger, B Assmus, MB Britten, J Honold, R Lehmann, C Teupe, ND Abolmaali, TJ Vogl, WK Hofmann, H Martin, S Dimmeler, AM Zeiher: Transplantation of progenitor cells and regeneration enhancement in acute myocardial infarction: final one-year results of the TOPCARE-AMI Trial. J Am Coll Cardiol 44, 1690-1699 (2004)

DOI: 10.1016/j.jacc.2004.08.014

21. HJ Kang, HS Kim, SY Zhang, KW Park, HJ Cho, BK Koo, YJ Kim, D Soo Lee, DW Sohn, KS Han, BH Oh, MM Lee, YB Park: Effects of intracoronary infusion of peripheral blood stem-cells mobilised with granulocyte-colony stimulating factor on left ventricular systolic function and restenosis after coronary stenting in myocardial infarction: the MAGIC cell randomised clinical trial. Lancet 363 , 751-756 (2004)

DOI: 10.1016/S0140-6736(04)15689-4

22. $V$ Schachinger, $S$ Erbs, A Elsasser, W Haberbosch, R Hambrecht, H Holschermann, J Yu, R Corti, DG Mathey, CW Hamm, T Suselbeck, B Assmus, T Tonn, S Dimmeler, AM Zeiher: Intracoronary bone marrow-derived progenitor cells in acute myocardial infarction. N Engl J Med 355, 1210-1221 (2006) DOI: $10.1056 /$ NEJMoa060186

23. KC Wollert, GP Meyer, J Lotz, S RingesLichtenberg, P Lippolt, C Breidenbach, S Fichtner, T Korte, B Hornig, D Messinger, L Arseniev, B Hertenstein, A Ganser, H Drexler: Intracoronary autologous bone-marrow cell transfer after myocardial infarction: the BOOST randomised controlled clinical trial. Lancet 364, 141-148 (2004)

DOI: 10.1016/S0140-6736(04)16626-9

24. AJ Friedenstein, RK Chailakhjan, KS Lalykina: The development of fibroblast colonies in monolayer cultures of guinea-pig bone marrow and spleen cells. Cell Tissue Kinet 3 , 393-403 (1970)

DOI: 10.1111/j.1365-2184.1970.tb00347.x

25. MF Pittenger, AM Mackay, SC Beck, RK Jaiswal, R Douglas, JD Mosca, MA Moorman, DW Simonetti, S Craig, DR Marshak: Multilineage potential of adult human mesenchymal stem cells. Science 284, 143-147 (1999)

DOI: $10.1126 /$ science.284.5411.143

26. C Siciliano, I Chimenti, M Ibrahim, C Napoletano, G Mangino, G Scafetta, GB Zoccai, EA Rendina, A Calogero, G Frati, E De Falco: Cardiosphere Conditioned Media Influence the Plasticity of Human Mediastinal Adipose Tissue-Derived Mesenchymal Stem 
Cells. Cell Transplant, (2015)

DOI: 10.3727/096368914X5771

27. C Siciliano, M Ibrahim, G Scafetta, C Napoletano, G Mangino, L Pierelli, G Frati, $E$ De Falco: Optimization of the isolation and expansion method of human mediastinaladipose tissue derived mesenchymal stem cells with virally inactivated GMPgrade platelet lysate. Cytotechnology 67, 165-174 (2015)

DOI: $10.1007 / \mathrm{s} 10616-013-9667-y$

28. M Dominici, K Le Blanc, I Mueller, I SlaperCortenbach, F Marini, D Krause, R Deans, A Keating, D Prockop, E Horwitz: Minimal criteria for defining multipotent mesenchymal stromal cells. The International Society for Cellular Therapy position statement. Cytotherapy 8, 315-317 (2006)

DOI: $10.1080 / 14653240600855905$

29. S Makino, K Fukuda, S Miyoshi, F Konishi, H Kodama, J Pan, M Sano, T Takahashi, S Hori, H Abe, J Hata, A Umezawa, S Ogawa: Cardiomyocytes can be generated from marrow stromal cells in vitro. J Clin Invest 103, 697-705 (1999)

DOI: $10.1172 / \mathrm{JCl} 5298$

30. S Rangappa, JW Entwistle, AS Wechsler, JY Kresh: Cardiomyocyte-mediated contact programs human mesenchymal stem cells to express cardiogenic phenotype. J Thorac Cardiovasc Surg 126, 124-132 (2003) DOI: 10.1016/S0022-5223(03)00074-6

31. W Xu, X Zhang, H Qian, W Zhu, X Sun, J Hu, $H$ Zhou, Y Chen: Mesenchymal stem cells from adult human bone marrow differentiate into a cardiomyocyte phenotype in vitro. Exp Biol Med (Maywood) 229, 623-631 (2004) [doi not found]

32. I Moscoso, A Centeno, E Lopez, JI RodriguezBarbosa, I Santamarina, P Filgueira, MJ Sanchez, R Dominguez-Perles, G PenuelasRivas, N Domenech: Differentiation "in vitro" of primary and immortalized porcine mesenchymal stem cells into cardiomyocytes for cell transplantation. Transplant Proc 37, 481-482 (2005)

DOI: 10.1016/j.transproceed.2004.12.247

33. B Balana, C Nicoletti, I Zahanich, EM Graf, T Christ, S Boxberger, U Ravens: 5-Azacytidine induces changes in electrophysiological properties of human mesenchymal stem cells.
Cell Res 16, 949-960 (2006)

DOI: 10.1038/sj.cr.7310116

34. C Toma, MF Pittenger, KS Cahill, BJ Byrne, PD Kessler: Human mesenchymal stem cells differentiate to a cardiomyocyte phenotype in the adult murine heart. Circulation 105, 93-98 (2002)

DOI: $10.1161 / \mathrm{hc0} 0102.101442$

35. JG Shake, PJ Gruber, WA Baumgartner, G Senechal, J Meyers, JM Redmond, MF Pittenger, BJ Martin: Mesenchymal stem cell implantation in a swine myocardial infarct model: engraftment and functional effects. Ann Thorac Surg 73, 1919-1925; discussion 1926 (2002)

DOI: 10.1016/S0003-4975(02)03517-8

36. LC Amado, AP Saliaris, KH Schuleri, M St John, JS Xie, S Cattaneo, DJ Durand, T Fitton, JQ Kuang, G Stewart, S Lehrke, WW Baumgartner, BJ Martin, AW Heldman, JM Hare: Cardiac repair with intramyocardial injection of allogeneic mesenchymal stem cells after myocardial infarction. Proc Natl Acad Sci U S A 102, 11474-11479 (2005) DOI: 10.1073/pnas.0504388102

37. J Feygin, A Mansoor, P Eckman, C Swingen, $J$ Zhang: Functional and bioenergetic modulations in the infarct border zone following autologous mesenchymal stem cell transplantation. Am J Physiol Heart Circ Physiol 293, H1772-1780 (2007) DOI: 10.1152/ajpheart.00242.2007

38. SM Nassiri, Z Khaki, M Soleimani, SH Ahmadi, I Jahanzad, S Rabbani, M Sahebjam, FA Ardalan, MS Fathollahi: The similar effect of transplantation of marrow-derived mesenchymal stem cells with or without prior differentiation induction in experimental myocardial infarction. J Biomed Sci 14, 745-755 (2007)

DOI: $10.1007 / \mathrm{s} 11373-007-9188-9$

39. C Siciliano, I Chimenti, A Bordin, D Ponti, P ludicone, M Peruzzi, EA Rendina, A Calogero, L Pierelli, M Ibrahim, E De Falco: The Potential of GMP-Compliant Platelet Lysate to Induce a Permissive State for Cardiovascular Transdifferentiation in Human Mediastinal Adipose Tissue-Derived Mesenchymal Stem Cells. Biomed Res Int 10, (2015)

DOI: 10. 10.1155/2015/162439

40. JK Salabei, PK Lorkiewicz, CR Holden, Q 
Li, KU Hong, R Bolli, A Bhatnagar, BG Hill: Glutamine Regulates Cardiac Progenitor Cell Metabolism and Proliferation. Stem Cells 33, 2613-2627 (2015)

DOI: $10.1002 /$ stem.2047

41. F Mosna, L Sensebe, M Krampera: Human bone marrow and adipose tissue mesenchymal stem cells: a user's guide. Stem Cells Dev 19, 1449-1470 (2010)

DOI: $10.1089 / \mathrm{scd} .2010 .0140$

42. S Rangappa, C Fen, EH Lee, A Bongso, EK Sim: Transformation of adult mesenchymal stem cells isolated from the fatty tissue into cardiomyocytes. Ann Thorac Surg 75, 775-779 (2003)

DOI: 10.1016/S0003-4975(02)04568-X

43. W Chang, S Lim, BW Song, CY Lee, MS Park, YA Chung, C Yoon, SY Lee, O Ham, JH Park, E Choi, LS Maeng, KC Hwang: Phorbol myristate acetate differentiates human adipose-derived mesenchymal stem cells into functional cardiogenic cells. Biochem Biophys Res Commun 424, 740-746 (2012)

DOI: 10.1016/j.bbrc.2012.07.022

44. KG Gaustad, AC Boquest, BE Anderson, AM Gerdes, P Collas: Differentiation of human adipose tissue stem cells using extracts of rat cardiomyocytes. Biochem Biophys Res Commun 314, 420-427 (2004)

DOI: 10.1016/j.bbrc.2003.12.109

45. YH Song, S Gehmert, S Sadat, K Pinkernell, $X$ Bai, N Matthias, E Alt: VEGF is critical for spontaneous differentiation of stem cells into cardiomyocytes. Biochem Biophys Res Commun 354, 999-1003 (2007)

DOI: 10.1016/j.bbrc.2007.01.095

46. A van Dijk, HW Niessen, B Zandieh Doulabi, FC Visser, FJ van Milligen: Differentiation of human adipose-derived stem cells towards cardiomyocytes is facilitated by laminin. Cell Tissue Res 334, 457-467 (2008)

DOI: 10.1007/s00441-008-0713-6

47. M Peran, JA Marchal, E Lopez, M JimenezNavarro, H Boulaiz, F Rodriguez-Serrano, E Carrillo, G Sanchez-Espin, E de Teresa, D Tosh, A Aranega: Human cardiac tissue induces transdifferentiation of adult stem cells towards cardiomyocytes. Cytotherapy 12, 332-337 (2010)

DOI: 10.3109/14653240903548202
48. V Planat-Benard, C Menard, M Andre, M Puceat, A Perez, JM Garcia-Verdugo, L Penicaud, L Casteilla: Spontaneous cardiomyocyte differentiation from adipose tissue stroma cells. Circ Res 94, 223-229 (2004)

DOI: 10.1161/01.RES.0000109792.43271.47

49. M Rigol, N Solanes, S Roura, M Roque, L Novensa, AP Dantas, J Martorell, M Sitges, J Ramirez, A Bayes-Genis, M Heras: Allogeneic adipose stem cell therapy in acute myocardial infarction. Eur J Clin Invest 44, 83-92 (2014) DOI: 10.1111/eci.12195

50. A van Dijk, BA Naaijkens, WJ Jurgens, K Nalliah, S Sairras, RJ van der Pijl, K Vo, AB Vonk, AC van Rossum, WJ Paulus, FJ van Milligen, HW Niessen: Reduction of infarct size by intravenous injection of uncultured adipose derived stromal cells in a rat model is dependent on the time point of application. Stem Cell Res 7, 219-229 (2011)

DOI: 10.1016/j.scr.2011.06.003

51. L Wang, J Deng, W Tian, B Xiang, T Yang, G Li, J Wang, M Gruwel, T Kashour, J Rendell, M Glogowski, B Tomanek, D Freed, R Deslauriers, RC Arora, G Tian: Adiposederived stem cells are an effective cell candidate for treatment of heart failure: an MR imaging study of rat hearts. Am J Physiol Heart Circ Physiol 297, H1020-1031 (2009)

DOI: 10.1152/ajpheart.01082.2008

52. LH Yu, MH Kim, TH Park, KS Cha, YD Kim, ML Quan, MS Rho, SY Seo, JS Jung: Improvement of cardiac function and remodeling by transplanting adipose tissuederived stromal cells into a mouse model of acute myocardial infarction. Int J Cardiol 139, 166-172 (2010)

DOI: 10.1016/j.ijcard.2008.10.024

53. R De Siena, L Balducci, A Blasi, MG Montanaro, M Saldarelli, V Saponaro, C Martino, G Logrieco, A Soleti, S Fiobellot, P Madeddu, G Rossi, D Ribatti, A Crovace, S Cristini, G Invernici, EA Parati, G Alessandri: Omentum-derived stromal cells improve myocardial regeneration in pig post-infarcted heart through a potent paracrine mechanism. Exp Cell Res 316, 1804-1815 (2010)

DOI: 10.1016/j.yexcr.2010.02.009

54. M Mazo, S Hernandez, JJ Gavira, GAbizanda, M Arana, T Lopez-Martinez, C Moreno, J 
Merino, A Martino-Rodriguez, A Uixeira, JA Garcia de Jalon, J Pastrana, D Martinez-Caro, F Prosper: Treatment of reperfused ischemia with adipose-derived stem cells in a preclinical Swine model of myocardial infarction. Cell Transplant 21, 2723-2733 (2012) DOI: $10.3727 / 096368912 X 638847$

55. JH Houtgraaf, WK den Dekker, BM van Dalen, $\mathrm{T}$ Springeling, $\mathrm{R}$ de Jong, $\mathrm{RJ}$ van Geuns, ML Geleijnse, F Fernandez-Aviles, F Zijlsta, PW Serruys, HJ Duckers: First experience in humans using adipose tissuederived regenerative cells in the treatment of patients with ST-segment elevation myocardial infarction. J Am Coll Cardiol 59, 539-540 (2012)

DOI: 10.1016/j.jacc.2011.09.065

56. EC Perin, R Sanz-Ruiz, PL Sanchez, J Lasso, R Perez-Cano, JC Alonso-Farto, E PerezDavid, ME Fernandez-Santos, PW Serruys, HJ Duckers, J Kastrup, S Chamuleau, Y Zheng, GV Silva, JT Willerson, F FernandezAviles: Adipose-derived regenerative cells in patients with ischemic cardiomyopathy: The PRECISE Trial. Am Heart J 168, 88-95 e82 (2014)

DOI: 10.1016/j.ahj.2014.03.022

57. AA Qayyum, M Haack-Sorensen, $A B$ Mathiasen, E Jorgensen, A Ekblond, J Kastrup: Adipose-derived mesenchymal stromal cells for chronic myocardial ischemia (MyStromalCell Trial): study design. Regen Med 7, 421-428 (2012)

DOI: $10.2217 /$ rme.12.17

58. L Chen, F Qin, M Ge, Q Shu, J Xu: Application of adipose-derived stem cells in heart disease. J Cardiovasc Transl Res 7, 651-663 (2014) DOI: $10.1007 / \mathrm{s} 12265-014-9585-1$

59. G Veronica, RR Esther: Aging, metabolic syndrome and the heart. Aging Dis 3, 269-279 (2012)

doi not found

60. BJ North, DA Sinclair: The intersection between aging and cardiovascular disease. Circ Res 110, 1097-1108 (2012)

DOI: 10.1161/CIRCRESAHA.111.246876

61. L Oburoglu, S Tardito, V Fritz, SC de Barros, P Merida, M Craveiro, J Mamede, G Cretenet, C Mongellaz, X An, D Klysz, J Touhami, M Boyer-Clavel, JL Battini, V Dardalhon, VS Zimmermann, N Mohandas, E Gottlieb,
M Sitbon, S Kinet, N Taylor: Glucose and glutamine metabolism regulate human hematopoietic stem cell lineage specification. Cell Stem Cell 15, 169-184 (2014)

DOI: 10.1016/j.stem.2014.06.002

62. JM Ryu, HJ Lee, YH Jung, KH Lee, DI Kim, JY Kim, SH Ko, GE Choi, Chai, II, EJ Song, JY Oh, SJ Lee, HJ Han: Regulation of Stem Cell Fate by ROS-mediated Alteration of Metabolism. Int J Stem Cells 8, 24-35 (2015) DOI: 10.15283/ijsc.2015.8.1.24

63. PJ Psaltis, RD Simari: Vascular wall progenitor cells in health and disease. Circ Res 116, 1392-1412 (2015)

DOI: 10.1161/CIRCRESAHA.116.305368

64. S Sart, L Song, Y Li: Controlling Redox Status for Stem Cell Survival, Expansion, and Differentiation. Oxid Med Cell Longev 2015, 105135 (2015)

DOI: $10.1155 / 2015 / 105135$

65. A Prigione, MV Ruiz-Perez, R Bukowiecki, $J$ Adjaye: Metabolic restructuring and cell fate conversion. Cell Mol Life Sci 72, 1759-1777 (2015)

DOI: 10.1007/s00018-015-1834-1

66. KJ Ahlqvist, A Suomalainen, RH Hamalainen: Stem cells, mitochondria and aging. Biochim Biophys Acta 1847, 1380-1386 (2015)

DOI: 1016/j.bbabio.2015.05.014

67. KH Yiu, HF Tse: Specific role of impaired glucose metabolism and diabetes mellitus in endothelial progenitor cell characteristics and function. Arterioscler Thromb Vasc Biol 34, 1136-1143 (2014)

DOI: 10.1161/ATVBAHA.114.302192

68. S Dimmeler, A Leri: Aging and disease as modifiers of efficacy of cell therapy. Circ Res 102, 1319-1330 (2008)

DOI: 10.1161/CIRCRESAHA.108.175943

69. E Gambini, M Pesce, L Persico, B Bassetti, A Gambini, F Alamanni, M Agrifoglio, MC Capogrossi, G Pompilio: Patient profile modulates cardiac c-kit(+) progenitor cell availability and amplification potential. Transl Res 160, 363-373 (2012)

DOI: 10.1016/j.trsl.2012.05.009

70. A Ludke, RK Li, RD Weisel: The Rejuvenation of Aged Stem Cells for Cardiac Repair. Can J Cardiol 30, 1299-1306 (2014)

DOI: 10.1016/j.cjca.2014.03.021 
71. IM Conboy, MJ Conboy, AJ Wagers, ER Girma, IL Weissman, TA Rando: Rejuvenation of aged progenitor cells by exposure to a young systemic environment. Nature 433, 760-764 (2005)

DOI: $10.1038 /$ nature 03260

72. FS Loffredo, ML Steinhauser, SM Jay, J Gannon, JR Pancoast, P Yalamanchi, M Sinha, C Dall'Osso, D Khong, JL Shadrach, CM Miller, BS Singer, A Stewart, N Psychogios, RE Gerszten, AJ Hartigan, MJ Kim, T Serwold, AJ Wagers, RT Lee: Growth differentiation factor 11 is a circulating factor that reverses age-related cardiac hypertrophy. Cell 153, 828-839 (2013)

DOI: 10.1016/j.cell.2013.04.015

73. K Kang, L Sun, Y Xiao, SH Li, J Wu, J Guo, SL Jiang, L Yang, TM Yau, RD Weisel, M Radisic, RK Li: Aged human cells rejuvenated by cytokine enhancement of biomaterials for surgical ventricular restoration. J Am Coll Cardiol 60, 2237-2249 (2012)

DOI: $10.1016 / j$ j.jacc.2012.08.985

74. C Chimenti, J Kajstura, D Torella, K Urbanek, H Heleniak, C Colussi, F Di Meglio, B NadalGinard, A Frustaci, A Leri, A Maseri, P Anversa: Senescence and death of primitive cells and myocytes lead to premature cardiac aging and heart failure. Circ Res 93, 604-613 (2003) DOI: 10.1161/01.RES.0000093985.76901.AF

75. DJ Rossi, D Bryder, J Seita, A Nussenzweig, J Hoeijmakers, IL Weissman: Deficiencies in DNA damage repair limit the function of haematopoietic stem cells with age. Nature 447, 725-729 (2007)

DOI: 10.1038/nature05862

76. NE Sharpless, RA DePinho: How stem cells age and why this makes us grow old. Nat Rev Mol Cell Biol 8, 703-713 (2007)

DOI: $10.1038 / \mathrm{nrm} 2241$

77. F Sanada, J Kim, A Czarna, NY Chan, S Signore, B Ogorek, K Isobe, E Wybieralska, G Borghetti, A Pesapane, A Sorrentino, E Mangano, D Cappetta, C Mangiaracina, M Ricciardi, M Cimini, E Ifedigbo, MA Perrella, P Goichberg, AM Choi, J Kajstura, T Hosoda, M Rota, P Anversa, A Leri: c-Kit-positive cardiac stem cells nested in hypoxic niches are activated by stem cell factor reversing the aging myopathy. Circ Res 114, 41-55 (2014) DOI: 10.1161/CIRCRESAHA.114.302500
78. S Hu, G Yan, W He, Z Liu, H Xu, G Ma: The influence of disease and age on human cardiac stem cells. Ann Clin Biochem 51, 582-590 (2014)

DOI: $10.1177 / 0004563213511065$

79. J Kajstura, F Fiordaliso, AM Andreoli, BS $\mathrm{Li}$, S Chimenti, MS Medow, F Limana, B Nadal-Ginard, A Leri, P Anversa: IGF-1 overexpression inhibits the development of diabetic cardiomyopathy and angiotensin II-mediated oxidative stress. Diabetes 50, 1414-1424 (2001)

DOI: 10.2337/diabetes.50.6.1414

80. D Torella, M Rota, D Nurzynska, E Musso, A Monsen, I Shiraishi, E Zias, K Walsh, A Rosenzweig, MA Sussman, K Urbanek, B Nadal-Ginard, J Kajstura, P Anversa, A Leri: Cardiac stem cell and myocyte aging, heart failure, and insulin-like growth factor-1 overexpression. Circ Res 94, 514-524 (2004) DOI: 10.1161/01.RES.0000117306.10142.50

81. ME Davis, PC Hsieh, T Takahashi, Q Song, S Zhang, RD Kamm, AJ Grodzinsky, P Anversa, RT Lee: Local myocardial insulin-like growth factor 1 (IGF-1) delivery with biotinylated peptide nanofibers improves cell therapy for myocardial infarction. Proc Natl Acad Sci U S A 103, 8155-8160 (2006)

DOI: $10.1073 /$ pnas. 0602877103

82. C Kenyon: The plasticity of aging: insights from long-lived mutants. Cell 120, 449-460 (2005) DOI: 10.1016/j.cell.2005.02.002

83. A Gonzalez, M Rota, D Nurzynska, Y Misao, J Tillmanns, C Ojaimi, ME Padin-Iruegas, P Muller, G Esposito, C Bearzi, S Vitale, B Dawn, SK Sanganalmath, M Baker, TH Hintze, R Bolli, K Urbanek, T Hosoda, P Anversa, J Kajstura, A Leri: Activation of cardiac progenitor cells reverses the failing heart senescent phenotype and prolongs lifespan. Circ Res 102, 597-606 (2008) DOI: 10.1161/CIRCRESAHA.107.165464

84. S Kawanishi, S Oikawa: Mechanism of telomere shortening by oxidative stress. Ann N Y Acad Sci 1019, 278-284 (2004)

DOI: 10.1196/annals.1297.047

85. O Kollet, S Shivtiel, YQ Chen, J Suriawinata, SN Thung, MD Dabeva, J Kahn, A Spiegel, A Dar, S Samira, P Goichberg, A Kalinkovich, F Arenzana-Seisdedos, A Nagler, I Hardan, M Revel, DA Shafritz, T Lapidot: HGF, SDF-1, 
and MMP-9 are involved in stress-induced human CD34+ stem cell recruitment to the liver. J Clin Invest 112, 160-169 (2003)

DOI: $10.1172 / \mathrm{JCl} 17902$

86. A Linke, P Muller, D Nurzynska, C Casarsa, D Torella, A Nascimbene, C Castaldo, S Cascapera, M Bohm, F Quaini, K Urbanek, A Leri, TH Hintze, J Kajstura, P Anversa: Stem cells in the dog heart are self-renewing, clonogenic, and multipotent and regenerate infarcted myocardium, improving cardiac function. Proc Natl Acad Sci U S A 102, 8966-8971 (2005)

DOI: $10.1073 /$ pnas.0502678102

87. EU Alt, C Senst, SN Murthy, DP Slakey, CL Dupin, AE Chaffin, PJ Kadowitz, R Izadpanah: Aging alters tissue resident mesenchymal stem cell properties. Stem Cell Res 8, 215-225 (2012)

DOI: 10.1016/j.scr.2011.11.002

88. A Efimenko, N Dzhoyashvili, N Kalinina, $T$ Kochegura, R Akchurin, $V$ Tkachuk, $Y$ Parfyonova: Adipose-derived mesenchymal stromal cells from aged patients with coronary artery disease keep mesenchymal stromal cell properties but exhibit characteristics of aging and have impaired angiogenic potential. Stem Cells Transl Med 3, 32-41 (2014)

DOI: $10.5966 /$ sctm.2013-0014

89. M Fan, W Chen, W Liu, GQ Du, SL Jiang, WC Tian, L Sun, RK Li, H Tian: The effect of age on the efficacy of human mesenchymal stem cell transplantation after a myocardial infarction. Rejuvenation Res 13, 429-438 (2010)

DOI: 10.1089/rej.2009.0986

90. Y Zhuo, SH Li, MS Chen, J Wu, HY Kinkaid, S Fazel, RD Weisel, RK Li: Aging impairs the angiogenic response to ischemic injury and the activity of implanted cells: combined consequences for cell therapy in older recipients. J Thorac Cardiovasc Surg 139, 1286-1294, 1294 e1281-1282 (2010)

DOI: $10.1016 / j . j t c v s .2009 .08 .052$

91. RG Turan, $M$ Brehm, M Koestering, Z Tobias, T Bartsch, S Steiner, F Picard, P Ebner, CM Schannwell, BE Strauer: Factors influencing spontaneous mobilization of CD34+ and CD133+ progenitor cells after myocardial infarction. Eur J Clin Invest 37, 842-851 (2007) DOI: 10.1111/j.1365-2362.2007.01876.x

92. AM Mozid, D Jones, S Arnous, N Saunders,
A Wragg, J Martin, S Agrawal, A Mathur: The effects of age, disease state, and granulocyte colony-stimulating factor on progenitor cell count and function in patients undergoing cell therapy for cardiac disease. Stem Cells Dev 22, 216-223 (2013)

DOI: $10.1089 / \mathrm{scd} .2012 .0139$

93. SH Li, Z Sun, KR Brunt, X Shi, MS Chen, RD Weisel, RK Li: Reconstitution of aged bone marrow with young cells repopulates cardiacresident bone marrow-derived progenitor cells and prevents cardiac dysfunction after a myocardial infarction. Eur Heart $J$ 34, 1157-1167 (2013)

DOI: 10.1093/eurheartj/ehs072

94. RC Allsopp, S Cheshier, IL Weissman: Telomerase activation and rejuvenation of telomere length in stimulated $\mathrm{T}$ cells derived from serially transplanted hematopoietic stem cells. J Exp Med 196, 1427-1433 (2002)

DOI: 10.1084/jem.20021003

95. K Sudo, H Ema, Y Morita, H Nakauchi: Age-associated characteristics of murine hematopoietic stem cells. J Exp Med 192, 1273-1280 (2000)

DOI: 10.1084/jem.192.9.1273

96. Z Xing, MA Ryan, D Daria, KJ Nattamai, G Van Zant, L Wang, Y Zheng, H Geiger: Increased hematopoietic stem cell mobilization in aged mice. Blood 108, 2190-2197 (2006)

DOI: 10.1182/blood-2005-12-010272

97. I Spyridopoulos, Y Erben, TH Brummendorf, J Haendeler, K Dietz, F Seeger, CK Kissel, H Martin, J Hoffmann, B Assmus, AM Zeiher, $S$ Dimmeler: Telomere gap between granulocytes and lymphocytes is a determinant for hematopoetic progenitor cell impairment in patients with previous myocardial infarction. Arterioscler Thromb Vasc Biol 28, 968-974 (2008)

DOI: 10.1161/ATVBAHA.107.160846

98. M Vasa, S Fichtlscherer, A Aicher, K Adler, C Urbich, H Martin, AM Zeiher, S Dimmeler: Number and migratory activity of circulating endothelial progenitor cells inversely correlate with risk factors for coronary artery disease. Circ Res 89, E1-7 (2001)

DOI: $10.1161 / \mathrm{hh} 1301.093953$

99. JM Edelberg, L Tang, K Hattori, D Lyden, $S$ Rafii: Young adult bone marrowderived endothelial precursor cells restore 
aging-impaired cardiac angiogenic function. Circ Res 90, E89-93 (2002)

DOI: 10.1161/01.RES.0000020861.20064.7E

100. X Xu, J Ren: Cardiac stem cell regeneration in metabolic syndrome. Curr Pharm Des 19, 4888-4892 (2013)

DOI: $10.2174 / 1381612811319270011$

101. PE Westerweel, FL Visseren, GR Hajer, JK Olijhoek, IE Hoefer, P de Bree, S Rafii, PA Doevendans, MC Verhaar: Endothelial progenitor cell levels in obese men with the metabolic syndrome and the effect of simvastatin monotherapy vs. simvastatin/ ezetimibe combination therapy. Eur Heart $J$ 29, 2808-2817 (2008)

DOI: 10.1093/eurheartj/ehn431

102. E Mansilla, V Diaz Aquino, D Zambon, GH Marin, K Martire, G Roque, T Ichim, NH Riordan, A Patel, F Sturla, G Larsen, R Spretz, L Nunez, C Soratti, R Ibar, M van Leeuwen, JM Tau, H Drago, A Maceira: Could metabolic syndrome, lipodystrophy, and aging be mesenchymal stem cell exhaustion syndromes? Stem Cells Int 2011, 943216 (2011)

DOI: $10.4061 / 2011 / 943216$

103. M Satoh, $Y$ Ishikawa, $Y$ Takahashi, $T$ Itoh, $Y$ Minami, M Nakamura: Association between oxidative DNA damage and telomere shortening in circulating endothelial progenitor cells obtained from metabolic syndrome patients with coronary artery disease. Atherosclerosis 198, 347-353 (2008)

DOI: 10.1016/j.atherosclerosis.2007.09.040

104. M Rota, N LeCapitaine, T Hosoda, A Boni, A De Angelis, ME Padin-Iruegas, G Esposito, S Vitale, K Urbanek, C Casarsa, M Giorgio, TF Luscher, PG Pelicci, P Anversa, A Leri, J Kajstura: Diabetes promotes cardiac stem cell aging and heart failure, which are prevented by deletion of the p66shc gene. Circ Res 99, 42-52 (2006)

DOI: 10.1161/01.RES.0000231289.63468.08

105. G Olivetti, M Melissari, T Balbi, F Quaini, EH Sonnenblick, P Anversa: Myocyte nuclear and possible cellular hyperplasia contribute to ventricular remodeling in the hypertrophic senescent heart in humans. J Am Coll Cardiol 24, 140-149 (1994)

DOI:10.1016/0735-1097(94)90554-1

106. J Kajstura, K Urbanek, M Rota, C Bearzi, T
Hosoda, R Bolli, P Anversa, A Leri: Cardiac stem cells and myocardial disease. J Mol Cell Cardiol 45, 505-513 (2008)

DOI: 10.1016/j.yjmcc.2008.05.025

107. J Ferreira-Martins, C Rondon-Clavo, D Tugal, JA Korn, R Rizzi, ME Padin-Iruegas, S Ottolenghi, A De Angelis, K Urbanek, N Ide-Iwata, D D'Amario, T Hosoda, A Leri, J Kajstura, P Anversa, M Rota: Spontaneous calcium oscillations regulate human cardiac progenitor cell growth. Circ Res 105, 764-774 (2009)

DOI: 10.1161/CIRCRESAHA.109.206698

108. F Fiordaliso, A Leri, D Cesselli, F Limana, B Safai, B Nadal-Ginard, P Anversa, J Kajstura: Hyperglycemia activates p53 and p53-regulated genes leading to myocyte cell death. Diabetes 50, 2363-2375 (2001)

DOI: $10.2337 /$ diabetes.50.10.2363

109. D Bastianelli, C Siciliano, R Puca, A Coccia, C Murdoch, A Bordin, G Mangino, G Pompilio, A Calogero, E De Falco: Influence of Egr-1 in cardiac tissue-derived mesenchymal stem cells in response to glucose variations. Biomed Res Int 2014, 254793 (2014)

DOI: $10.1155 / 2014 / 254793$

110. R Katare, A Oikawa, D Cesselli, AP Beltrami, E Avolio, D Muthukrishnan, PE Munasinghe, G Angelini, C Emanueli, P Madeddu: Boosting the pentose phosphate pathway restores cardiac progenitor cell availability in diabetes. Cardiovasc Res 97, 55-65 (2013)

DOI: $10.1093 / c v r / c v s 291$

111. AS Molgat, EL Tilokee, G Rafatian, B Vulesevic, M Ruel, R Milne, EJ Suuronen, DR Davis: Hyperglycemia inhibits cardiac stem cell-mediated cardiac repair and angiogenic capacity. Circulation 130, S70-76 (2014)

DOI: $\quad 10.1161 / C I R C U L A T I O N A H A .113$ .007908

112. A Rossini, C Frati, C Lagrasta, G Graiani, A Scopece, S Cavalli, E Musso, M Baccarin, M Di Segni, F Fagnoni, A Germani, E Quaini, M Mayr, Q Xu, A Barbuti, D DiFrancesco, G Pompilio, F Quaini, C Gaetano, MC Capogrossi: Human cardiac and bone marrow stromal cells exhibit distinctive properties related to their origin. Cardiovasc Res 89, 650-660 (2011)

DOI: $10.1093 / c v r / c v q 290$

113. M Vecellio, F Spallotta, S Nanni, C Colussi, 
C Cencioni, A Derlet, B Bassetti, M Tilenni, MC Carena, A Farsetti, G Sbardella, S Castellano, A Mai, F Martelli, G Pompilio, MC Capogrossi, A Rossini, S Dimmeler, A Zeiher, C Gaetano: The histone acetylase activator pentadecylidenemalonate $1 \mathrm{~b}$ rescues proliferation and differentiation in the human cardiac mesenchymal cells of type 2 diabetic patients. Diabetes 63, 2132-2147 (2014) DOI: $10.2337 / \mathrm{db} 13-0731$

114. C Cramer, E Freisinger, RK Jones, DP Slakey, CL Dupin, ER Newsome, EU Alt, $\mathrm{R}$ Izadpanah: Persistent high glucose concentrations alter the regenerative potential of mesenchymal stem cells. Stem Cells Dev 19, 1875-1884 (2010)

DOI: $10.1089 / \mathrm{scd} .2010 .0009$

115. PD Lambiase, RJ Edwards, P Anthopoulos, S Rahman, YG Meng, CA Bucknall, SR Redwood, JD Pearson, MS Marber: Circulating humoral factors and endothelial progenitor cells in patients with differing coronary collateral support. Circulation 109, 2986-2992 (2004)

DOI: 10.1161/01.CIR.0000130639.97284.EC

116. OM Tepper, RD Galiano, JM Capla, C Kalka, PJ Gagne, GR Jacobowitz, JP Levine, GC Gurtner: Human endothelial progenitor cells from type II diabetics exhibit impaired proliferation, adhesion, and incorporation into vascular structures. Circulation 106, 2781-2786 (2002)

DOI: 10.1161/01.CIR.0000039526.42991.93

117. E De Falco, D Avitabile, P Totta, S Straino, F Spallotta, C Cencioni, AR Torella, R Rizzi, D Porcelli, A Zacheo, L Di Vito, G Pompilio, M Napolitano, G Melillo, MC Capogrossi, M Pesce: Altered SDF-1-mediated differentiation of bone marrow-derived endothelial progenitor cells in diabetes mellitus. J Cell Mol Med 13, 3405-3414 (2009)

DOI: $10.1111 / j .1582-4934.2009 .00655 . x$

118. J Hur, CH Yoon, HS Kim, JH Choi, HJ Kang, KK Hwang, BH Oh, MM Lee, YB Park: Characterization of two types of endothelial progenitor cells and their different contributions to neovasculogenesis. Arterioscler Thromb Vasc Biol 24, 288-293 (2004)

DOI: 10.1161/01.ATV.0000114236.77009.06

119. M Peichev, AJ Naiyer, D Pereira, Z Zhu, WJ Lane, M Williams, MC Oz, DJ Hicklin, L Witte,
MA Moore, S Rafii: Expression of VEGFR-2 and $\mathrm{AC} 133$ by circulating human CD34(+) cells identifies a population of functional endothelial precursors. Blood 95, 952-958 (2000)

[doi not found]

120. GP Fadini, M Miorin, M Facco, S Bonamico, I Baesso, F Grego, M Menegolo, SV de Kreutzenberg, A Tiengo, C Agostini, AAvogaro: Circulating endothelial progenitor cells are reduced in peripheral vascular complications of type 2 diabetes mellitus. J Am Coll Cardiol 45, 1449-1457 (2005)

DOI: 10.1016/j.jacc.2004.11.067

121. GP Fadini, S Sartore, M Albiero, I Baesso, E Murphy, M Menegolo, F Grego, S Vigili de Kreutzenberg, A Tiengo, C Agostini, A Avogaro: Number and function of endothelial progenitor cells as a marker of severity for diabetic vasculopathy. Arterioscler Thromb Vasc Biol 26, 2140-2146 (2006)

DOI: 10.1161/01.ATV.0000237750.44469.88

122. CJ Loomans, EJ de Koning, FJ Staal, MB Rookmaaker, C Verseyden, HC de Boer, MC Verhaar, B Braam, TJ Rabelink, AJ van Zonneveld: Endothelial progenitor cell dysfunction: a novel concept in the pathogenesis of vascular complications of type 1 diabetes. Diabetes 53, 195-199 (2004) DOI: $10.2337 /$ diabetes.53.1.195

123. C Urbich, S Dimmeler: Risk factors for coronary artery disease, circulating endothelial progenitor cells, and the role of HMG-CoA reductase inhibitors. Kidney Int 67, 1672-1676 (2005)

DOI: 10.1111/j.1523-1755.2005.00261.x

124. FH Seeger, J Haendeler, DH Walter, U Rochwalsky, J Reinhold, C Urbich, L Rossig, A Corbaz, Y Chvatchko, AM Zeiher, S Dimmeler: p38 mitogen-activated protein kinase downregulates endothelial progenitor cells. Circulation 111, 1184-1191 (2005) DOI: 10.1161/01.CIR.0000157156.85397.A1

125. GP Fadini, S Sartore, M Schiavon, M Albiero, I Baesso, A Cabrelle, C Agostini, A Avogaro: Diabetes impairs progenitor cell mobilisation after hindlimb ischaemia-reperfusion injury in rats. Diabetologia 49, 3075-3084 (2006) DOI: 10.1007/s00125-006-0401-6

126. GP Fadini, $P$ Madeddu, J Waltenberger, $P$ Fiorina: Vascular stem and progenitor cells in diabetic complications. Exp Diabetes Res 
2012, $580343(2012)$

DOI: $10.1155 / 2012 / 580343$

127. GP Fadini, A Avogaro: Diabetes impairs mobilization of stem cells for the treatment of cardiovascular disease: a meta-regression analysis. Int J Cardiol 168, 892-897 (2013) DOI: 10.1016/j.ijcard.2012.10.089

128. YH Chen, SJ Lin, FY Lin, TC Wu, CR Tsao, PH Huang, PL Liu, YL Chen, JW Chen: High glucose impairs early and late endothelial progenitor cells by modifying nitric oxiderelated but not oxidative stress-mediated mechanisms. Diabetes 56, 1559-1568 (2007) DOI: $10.2337 / \mathrm{db} 06-1103$

129. DA Ingram, IZ Lien, LE Mead, M Estes, DN Prater, E Derr-Yellin, LA DiMeglio, LS Haneline: In vitro hyperglycemia or a diabetic intrauterine environment reduces neonatal endothelial colony-forming cell numbers and function. Diabetes 57, 724-731 (2008)

DOI: $10.2337 / \mathrm{db} 07-1507$

130. HC Gerstein, ME Miller, RP Byington, DC Goff, Jr., JT Bigger, JB Buse, WC Cushman, $S$ Genuth, F Ismail-Beigi, RH Grimm, Jr., JL Probstfield, DG Simons-Morton, WT Friedewald: Effects of intensive glucose lowering in type 2 diabetes. $N$ Engl $\mathrm{J}$ Med 358, 2545-2559 (2008)

DOI: 10.1056/NEJMoa0802743

131. A Patel, S MacMahon, J Chalmers, B Neal, L Billot, M Woodward, M Marre, M Cooper, P Glasziou, D Grobbee, P Hamet, S Harrap, $S$ Heller, L Liu, G Mancia, CE Mogensen, C Pan, N Poulter, A Rodgers, B Williams, S Bompoint, BE de Galan, R Joshi, F Travert: Intensive blood glucose control and vascular outcomes in patients with type 2 diabetes. N Engl J Med 358, 2560-2572 (2008)

DOI: 10.1056/NEJMoa0802987

132. W Duckworth, C Abraira, T Moritz, D Reda, $\mathrm{N}$ Emanuele, PD Reaven, FJ Zieve, J Marks, SN Davis, R Hayward, SR Warren, S Goldman, M McCarren, ME Vitek, WG Henderson, GD Huang: Glucose control and vascular complications in veterans with type 2 diabetes. N Engl J Med 360, 129-139 (2009) DOI: 10.1056/NEJMoa0808431

133. $R$ Tamarat, JS Silvestre, $S$ Le RicousseRoussanne, $V$ Barateau, L LecomteRaclet, M Clergue, M Duriez, G Tobelem, $\mathrm{BI}$ Levy: Impairment in ischemia-induced neovascularization in diabetes: bone marrow mononuclear cell dysfunction and therapeutic potential of placenta growth factor treatment. Am J Pathol 164, 457-466 (2004)

DOI: 10.1016/S0002-9440(10)63136-7

134. CE Glass, PK Singal, DK Singla: Stem cells in the diabetic infarcted heart. Heart Fail Rev 15, 581-588 (2010)

DOI: $10.1007 / \mathrm{s} 10741-010-9172-8$

135. MG Dickinson, JH Ip, B Olshansky, AS Hellkamp, J Anderson, JE Poole, DB Mark, KL Lee, GH Bardy: Statin use was associated with reduced mortality in both ischemic and nonischemic cardiomyopathy and in patients with implantable defibrillators: mortality data and mechanistic insights from the Sudden Cardiac Death in Heart Failure Trial (SCDHeFT). Am Heart J 153, 573-578 (2007) DOI: 10.1016/j.ahj.2007.02.002

136. M Steinmetz, C Brouwers, G Nickenig, S Wassmann: Synergistic effects of telmisartan and simvastatin on endothelial progenitor cells. J Cell Mol Med 14, 1645-1656 (2010) DOI: 10.1111/j.1582-4934.2009.00829.x

137. B Assmus, C Urbich, A Aicher, WK Hofmann, J Haendeler, L Rossig, I Spyridopoulos, AM Zeiher, S Dimmeler: HMG-CoA reductase inhibitors reduce senescence and increase proliferation of endothelial progenitor cells via regulation of cell cycle regulatory genes. Circ Res 92, 1049-1055 (2003)

DOI: 10.1161/01.RES.0000070067.64040.7C

138. I Spyridopoulos, J Haendeler, C Urbich, TH Brummendorf, $\mathrm{H}$ Oh, MD Schneider, AM Zeiher, S Dimmeler: Statins enhance migratory capacity by upregulation of the telomere repeat-binding factor TRF2 in endothelial progenitor cells. Circulation 110, 3136-3142 (2004)

DOI: 10.1161/01.CIR.0000142866.50300.EB

139. T Thum, S Hoeber, S Froese, I Klink, DO Stichtenoth, P Galuppo, M Jakob, D Tsikas, SD Anker, PA Poole-Wilson, J Borlak, G Ertl, $J$ Bauersachs: Age-dependent impairment of endothelial progenitor cells is corrected by growth-hormone-mediated increase of insulin-like growth-factor-1. Circ Res 100, 434-443 (2007)

DOI: 10.1161/01.RES.0000257912.78915.af

140. KA Gallagher, ZJ Liu, M Xiao, H Chen, LJ Goldstein, DG Buerk, A Nedeau, SR Thom, 
OC Velazquez: Diabetic impairments in NO-mediated endothelial progenitor cell mobilization and homing are reversed by hyperoxia and SDF-1 alpha. J Clin Invest 117, 1249-1259 (2007)

DOI: $10.1172 / \mathrm{JCl} 29710$

141. PM Humpert, R Neuwirth, MJ Battista, $O$ Voronko, M von Eynatten, I Konrade, G Rudofsky, Jr., T Wendt, A Hamann, M Morcos, PP Nawroth, A Bierhaus: SDF-1 genotype influences insulin-dependent mobilization of adult progenitor cells in type 2 diabetes. Diabetes Care 28, 934-936 (2005)

DOI: 10.2337/diacare.28.4.934

142. B Vulesevic, B McNeill, M Geoffrion, D Kuraitis, JE McBane, M Lochhead, BC Vanderhyden, GS Korbutt, RW Milne, EJ Suuronen: Glyoxalase-1 overexpression in bone marrow cells reverses defective neovascularization in STZ-induced diabetic mice. Cardiovasc Res 101, 306-316 (2014)

DOI: $10.1093 / c v r / c v t 259$

143. FH Bahlmann, K de Groot, O Mueller, B Hertel, $\mathrm{H}$ Haller, D Fliser: Stimulation of endothelial progenitor cells: a new putative therapeutic effect of angiotensin II receptor antagonists. Hypertension 45, 526-529 (2005)

DOI: 10.1161/01.HYP.0000159191.98140.89

144. JKHan, HSLee, HMYang, JHur, SI Jun, JYKim, CHCho, GYKoh, JM Peters, KW Park, HJ Cho, HY Lee, HJ Kang, BH Oh, YB Park, HS Kim: Peroxisome proliferator-activated receptordelta agonist enhances vasculogenesis by regulating endothelial progenitor cells through genomic and nongenomic activations of the phosphatidylinositol 3-kinase/Akt pathway. Circulation 118, 1021-1033 (2008)

DOI: $\quad$ 10.1161/CIRCULATIONAHA.108. 777169

145. D Broqueres-You, C Lere-Dean, T MerkulovaRainon, CS Mantsounga, DAllanic, P Hainaud, JO Contreres, Y Wang, J Vilar, M Virally, JJ Mourad, PJ Guillausseau, JS Silvestre, BI Levy: Ephrin-B2-activated peripheral blood mononuclear cells from diabetic patients restore diabetes-induced impairment of postischemic neovascularization. Diabetes 61, 2621-2632 (2012)

DOI: $10.2337 / \mathrm{db} 11-1768$

146. GP Fadini, A Avogaro: Dipeptidyl peptidase-4 inhibition and vascular repair by mobilization of endogenous stem cells in diabetes and beyond. Atherosclerosis 229, 23-29 (2013)

DOI: 10.1016/j.atherosclerosis.2013.04.007

147. CH Wang, MK Ting, S Verma, LT Kuo, NI Yang, IC Hsieh, SY Wang, A Hung, WJ Cherng: Pioglitazone increases the numbers and improves the functional capacity of endothelial progenitor cells in patients with diabetes mellitus. Am Heart $J$ 152, 1051 e1051-1058 (2006)

DOI: 10.1016/j.ahj.2006.07.029

148. SA Sorrentino, FH Bahlmann, C Besler, M Muller, S Schulz, N Kirchhoff, C Doerries, T Horvath, A Limbourg, F Limbourg, D Fliser, H Haller, H Drexler, U Landmesser: Oxidant stress impairs in vivo reendothelialization capacity of endothelial progenitor cells from patients with type 2 diabetes mellitus: restoration by the peroxisome proliferatoractivated receptor-gamma agonist rosiglitazone. Circulation 116, 163-173 (2007) DOI: $\quad$ 10.1161/CIRCULATIONAHA.106. 684381

149. P Huang, S Li, M Han, Z Xiao, R Yang, ZC Han: Autologous transplantation of granulocyte colony-stimulating factor-mobilized peripheral blood mononuclear cells improves critical limb ischemia in diabetes. Diabetes Care 28, 2155-2160 (2005)

DOI: 10.2337/diacare.28.9.2155

150. N Urao, M Okigaki, H Yamada, Y Aadachi, K Matsuno, AMatsui, S Matsunaga, K Tateishi, T Nomura, TTakahashi, T Tatsumi, H Matsubara: Erythropoietin-mobilized endothelial progenitors enhance reendothelialization via Akt-endothelial nitric oxide synthase activation and prevent neointimal hyperplasia. Circ Res 98, 1405-1413 (2006)

DOI: 10.1161/01.RES.0000224117.59417.f3

151. K Strehlow, N Werner, J Berweiler, A Link, U Dirnagl, J Priller, K Laufs, L Ghaeni, M Milosevic, M Bohm, G Nickenig: Estrogen increases bone marrow-derived endothelial progenitor cell production and diminishes neointima formation. Circulation 107, 3059-3065 (2003)

DOI: 10.1161/01.CIR.0000077911.81151.30

152. C Kalka, H Tehrani, B Laudenberg, PR Vale, JM Isner, T Asahara, JF Symes: VEGF gene transfer mobilizes endothelial progenitor cells in patients with inoperable coronary disease. 
Ann Thorac Surg 70, 829-834 (2000)

DOI: 10.1016/S0003-4975(00)01633-7

153. RM Cubbon, MB Kahn, SB Wheatcroft: Effects of insulin resistance on endothelial progenitor cells and vascular repair. Clin Sci (Lond) 117, 173-190 (2009)

DOI: $10.1042 / C S 20080263$

154. F Liu, DD Chen, X Sun, HH Xie, H Yuan, W Jia, AF Chen: Hydrogen sulfide improves wound healing via restoration of endothelial progenitor cell functions and activation of angiopoietin-1 in type 2 diabetes. Diabetes 63, 1763-1778 (2014)

DOI: $10.2337 / \mathrm{db} 13-0483$

155. J Chang, Y Li, Y Huang, KS Lam, RL Hoo, WT Wong, KK Cheng, Y Wang, PM Vanhoutte, A $\mathrm{Xu}$ : Adiponectin prevents diabetic premature senescence of endothelial progenitor cells and promotes endothelial repair by suppressing the p38 MAP kinase/p16INK4A signaling pathway. Diabetes 59, 2949-2959 (2010)

DOI: $10.2337 / \mathrm{db} 10-0582$

156. S Meng, JT Cao, B Zhang, Q Zhou, CX Shen, CQ Wang: Downregulation of microRNA-126 in endothelial progenitor cells from diabetes patients, impairs their functional properties, via target gene Spred-1. J Mol Cell Cardiol 53, 64-72 (2012)

DOI: 10.1016/j.yjmcc.2012.04.003

157. S Meng, J Cao, X Zhang, Y Fan, L Fang, C Wang, Z Lv, D Fu, Y Li: Downregulation of microRNA-130a contributes to endothelial progenitor cell dysfunction in diabetic patients via its target Runx3. PLoS One 8, e68611 (2013)

DOI: 10.1371/journal.pone.0068611

158. BS Fleenor, AL Sindler, NK Marvi, KL Howell, ML Zigler, M Yoshizawa, DR Seals: Curcumin ameliorates arterial dysfunction and oxidative stress with aging. Exp Gerontol 48, 269-276 (2013)

DOI: 10.1016/j.exger.2012.10.008

159. R Motterlini, R Foresti, R Bassi, CJ Green: Curcumin, an antioxidant and anti-inflammatory agent, induces heme oxygenase- 1 and protects endothelial cells against oxidative stress. Free Radic Biol Med $28,1303-1312$ (2000)

DOI: 10.1016/S0891-5849(00)00294-X

160. J Liu, P Zhu, P Song, W Xiong, H Chen, W
Peng, S Wang, S Li, Z Fu, Y Wang, H Wang: Pretreatment of Adipose Derived Stem Cells with Curcumin Facilitates Myocardial Recovery via Antiapoptosis and Angiogenesis. Stem Cells Int 2015, 638153 (2015)

DOI: $10.1155 / 2015 / 638153$

161. YL Chen, CK Sun, TH Tsai, LT Chang, $S$ Leu, YY Zhen, JJ Sheu, S Chua, KH Yeh, HI Lu, HW Chang, FY Lee, HK Yip: Adiposederived mesenchymal stem cells embedded in platelet-rich fibrin scaffolds promote angiogenesis, preserve heart function, and reduce left ventricular remodeling in rat acute myocardial infarction. Am J Transl Res 7, 781-803 (2015)

[doi not found]

162. B Follin, M Juhl, S Cohen, AE Pedersen, M Gad, J Kastrup, A Ekblond: Human adiposederived stromal cells in a clinically applicable injectable alginate hydrogel: Phenotypic and immunomodulatory evaluation. Cytotherapy 17, 1104-1118 (2015)

DOI: 10.1016/j.jcyt.2015.04.008

163. R Madonna, L Petrov, MA Teberino, L Manzoli, JP Karam, FV Renna, P Ferdinandy, CN Montero-Menei, S Yla-Herttuala, R De Caterina: Transplantation of adipose tissue mesenchymal cells conjugated with VEGFreleasing microcarriers promotes repair in murine myocardial infarction. Cardiovasc Res, (2015)

DOI: $10.1093 / c v r / c v v 197$

164. X Yao, Y Liu, J Gao, L Yang, D Mao, C Stefanitsch, Y Li, J Zhang, L Ou, D Kong, Q Zhao, Z Li: Nitric oxide releasing hydrogel enhances the therapeutic efficacy of mesenchymal stem cells for myocardial infarction. Biomaterials 60, 130-140 (2015)

DOI: 10.1016/j.biomaterials.2015.04.046

165. F Limana, A Germani, A Zacheo, J Kajstura, A Di Carlo, G Borsellino, O Leoni, R Palumbo, L Battistini, R Rastaldo, S Muller, G Pompilio, $P$ Anversa, ME Bianchi, MC Capogrossi: Exogenous high-mobility group box 1 protein induces myocardial regeneration after infarction via enhanced cardiac C-kit+ cell proliferation and differentiation. Circ Res 97, e73-83 (2005)

DOI: 10.1161/01.RES.0000186276.06104.04

166. R Palumbo, ME Bianchi: High mobility group box 1 protein, a cue for stem cell recruitment. 
Biochem Pharmacol 68, 1165-1170 (2004)

DOI: 10.1016/j.bcp.2004.03.048

167. VF Segers, T Tokunou, LJ Higgins, C MacGillivray, J Gannon, RT Lee: Local delivery of protease-resistant stromal cell derived factor-1 for stem cell recruitment after myocardial infarction. Circulation 116, 1683-1692 (2007)

DOI: $\quad 10.1161 /$ CIRCULATIONAHA.107 .718718

168. AT Askari, S Unzek, ZB Popovic, CK Goldman, F Forudi, M Kiedrowski, A Rovner, SG Ellis, JD Thomas, PE DiCorleto, EJ Topol, MS Penn: Effect of stromal-cell-derived factor 1 on stem-cell homing and tissue regeneration in ischaemic cardiomyopathy. Lancet 362, 697-703 (2003)

DOI: 10.1016/S0140-6736(03)14232-8

169. JM Edelberg, D Cai, M Xaymardan: Translation of PDGF cardioprotective pathways. Cardiovasc Toxicol 3, 27-35 (2003) DOI: 10.1385/CT:3:1:27

170. H Kurosu, M Yamamoto, JD Clark, JV Pastor, A Nandi, P Gurnani, OP McGuinness, H Chikuda, M Yamaguchi, H Kawaguchi, I Shimomura, Y Takayama, J Herz, CR Kahn, KP Rosenblatt, M Kuro-o: Suppression of aging in mice by the hormone Klotho. Science 309, 1829-1833 (2005)

DOI: 10.1126/science.1112766

171. A Imura, A Iwano, O Tohyama, Y Tsuji, K Nozaki, N Hashimoto, T Fujimori, Y Nabeshima: Secreted Klotho protein in sera and CSF: implication for post-translational cleavage in release of Klotho protein from cell membrane. FEBS Lett 565, 143-147 (2004)

DOI: 10.1016/j.febslet.2004.03.090

172. Y Nabeshima: Toward a better understanding of Klotho. Sci Aging Knowledge Environ 2006, pe11 (2006)

DOI: 10.1126/sageke.2006.8.pe11

173. A Aicher, C Heeschen, K Sasaki, C Urbich, AM Zeiher, S Dimmeler: Low-energy shock wave for enhancing recruitment of endothelial progenitor cells: a new modality to increase efficacy of cell therapy in chronic hind limb ischemia. Circulation 114, 2823-2830 (2006) DOI: $\quad$ 10.1161/CIRCULATIONAHA.106. 628623

174. FM Rauscher, PJ Goldschmidt-Clermont, BH
Davis, T Wang, D Gregg, P Ramaswami, AM Pippen, BH Annex, C Dong, DA Taylor: Aging, progenitorcellexhaustion, and atherosclerosis. Circulation 108, 457-463 (2003)

DOI: 10.1161/01.CIR.0000082924.75945.48

175. C Heiss, S Keymel, U Niesler, J Ziemann, M Kelm, C Kalka: Impaired progenitor cell activity in age-related endothelial dysfunction. J Am Coll Cardiol 45, 1441-1448 (2005)

DOI: 10.1016/j.jacc.2004.12.074

176. SL Chen, WW Fang, F Ye, YH Liu, J Qian, SJ Shan, JJ Zhang, RZ Chunhua, LM Liao, S Lin, JP Sun: Effect on left ventricular function of intracoronary transplantation of autologous bone marrow mesenchymal stem cell in patients with acute myocardial infarction. Am J Cardiol 94, 92-95 (2004)

DOI: 10.1016/j.amjcard.2004.03.034

177. JM Hare: Translational development of mesenchymal stem cell therapy for cardiovascular diseases. Tex Heart Inst J 36, 145-147 (2009)

[doi not found]

178. K Malliaras, TS Li, D Luthringer, J Terrovitis, K Cheng, T Chakravarty, G Galang, Y Zhang, F Schoenhoff, J Van Eyk, L Marban, E Marban: Safety and efficacy of allogeneic cell therapy in infarcted rats transplanted with mismatched cardiosphere-derived cells. Circulation 125, 100-112 (2012)

DOI:10.1161/CIRCULATIONAHA.111.042598

179. D Belotti, G Gaipa, B Bassetti, B Cabiati, G Spaltro, E Biagi, M Parma, A Biondi, L Cavallotti, E Gambini, and G Pompilio: Full GMP-Compliant Validation of Bone MarrowDerived Human CD133+ Cells as Advanced Therapy Medicinal Product for Refractory Ischemic Cardiomyopathy. BioMed Res Int 10, (2015)

DOI: $10.1155 / 2015 / 473159$

180. G Vassalli, T Moccetti: Cardiac repair with allogeneic mesenchymal stem cells after myocardial infarction. Swiss Med Wkly 141, w13209 (2011)

DOI: 10.4414/smw.2011.13209

181. JM Hare, JH Traverse, TD Henry, N Dib, RK Strumpf, SP Schulman, G Gerstenblith, AN DeMaria, AE Denktas, RS Gammon, JB Hermiller, Jr., MA Reisman, GL Schaer, W Sherman: A randomized, double-blind, placebo-controlled, dose-escalation study 
of intravenous adult human mesenchymal stem cells (prochymal) after acute myocardial infarction. J Am Coll Cardiol 54, 2277-2286 (2009)

DOI: 10.1016/j.jacc.2009.06.055

182. MS Penn, S Ellis, S Gandhi, A Greenbaum, Z Hodes, FO Mendelsohn, D Strasser, AE Ting, W Sherman: Adventitial delivery of an allogeneic bone marrow-derived adherent stem cell in acute myocardial infarction: phase I clinical study. Circ Res 110, 304-311 (2012) DOI: 10.1161/CIRCRESAHA.111.253427

183. JM Ryan, FP Barry, JM Murphy, BP Mahon: Mesenchymal stem cells avoid allogeneic rejection. J Inflamm (Lond) 2, 8 (2005)

DOI: $10.1186 / 1476-9255-2-8$

184. I Rasmusson: Immune modulation by mesenchymal stem cells. Exp Cell Res 312, 2169-2179 (2006)

DOI: 10.1016/j.yexcr.2006.03.019

185. K Le Blanc, C Tammik, K Rosendahl, E Zetterberg, O Ringden: HLA expression and immunologic properties of differentiated and undifferentiated mesenchymal stem cells. Exp Hematol 31, 890-896 (2003) DOI: 10.1016/S0301-472X(03)00110-3

186. M Di Nicola, C Carlo-Stella, M Magni, M Milanesi, PD Longoni, P Matteucci, S Grisanti, AM Gianni: Human bone marrow stromal cells suppress T-lymphocyte proliferation induced by cellular or nonspecific mitogenic stimuli. Blood 99, 3838-3843 (2002)

DOI: 10.1182/blood.V99.10.3838

187. K Le Blanc, L Tammik, B Sundberg, SE Haynesworth, O Ringden: Mesenchymal stem cells inhibit and stimulate mixed lymphocyte cultures and mitogenic responses independently of the major histocompatibility complex. Scand J Immunol 57, 11-20 (2003) DOI: 10.1046/j.1365-3083.2003.01176.x

188. AJ Nauta, WE Fibbe: Immunomodulatory properties of mesenchymal stromal cells. Blood 110, 3499-3506 (2007)

DOI: 10.1182/blood-2007-02-069716

189. K Le Blanc, O Ringden: Immunobiology of human mesenchymal stem cells and future use in hematopoietic stem cell transplantation. Biol Blood Marrow Transplant 11, 321-334 (2005)

DOI: 10.1016/j.bbmt.2005.01.005
190. KW Liechty, TC MacKenzie, AF Shaaban, A Radu, AM Moseley, R Deans, DR Marshak, AW Flake: Human mesenchymal stem cells engraft and demonstrate site-specific differentiation after in utero transplantation in sheep. Nat Med 6, 1282-1286 (2000)

DOI: $10.1038 / 81395$

191. H Yagi, A Soto-Gutierrez, B Parekkadan, Y Kitagawa, RG Tompkins, N Kobayashi, ML Yarmush: Mesenchymal stem cells: Mechanisms of immunomodulation and homing. Cell Transplant 19, 667-679 (2010) DOI: $10.3727 / 096368910 \times 508762$

192. S Aggarwal, MF Pittenger: Human mesenchymal stem cells modulate allogeneic immune cell responses. Blood 105, 1815-1822 (2005)

DOI: 10.1182/blood-2004-04-1559

193. A Bartholomew, C Sturgeon, M Siatskas, K Ferrer, K Mclntosh, S Patil, W Hardy, S Devine, D Ucker, R Deans, A Moseley, R Hoffman: Mesenchymal stem cells suppress lymphocyte proliferation in vitro and prolong skin graft survival in vivo. Exp Hematol 30, 42-48 (2002)

DOI: $10.1016 / S 0301-472 X(01) 00769-X$

194. K Le Blanc, F Frassoni, L Ball, F Locatelli, H Roelofs, I Lewis, E Lanino, B Sundberg, ME Bernardo, M Remberger, G Dini, RM Egeler, A Bacigalupo, W Fibbe, O Ringden: Mesenchymal stem cells for treatment of steroid-resistant, severe, acute graft-versushost disease: a phase II study. Lancet 371 , 1579-1586 (2008)

DOI: 10.1016/S0140-6736(08)60690-X

195. EM Horwitz, PL Gordon, WK Koo, JC Marx, MD Neel, RY McNall, L Muul, T Hofmann: Isolated allogeneic bone marrow-derived mesenchymal cells engraft and stimulate growth in children with osteogenesis imperfecta: Implications for cell therapy of bone. Proc Natl Acad Sci U S A 99, 8932-8937 (2002)

DOI: 10.1073/pnas.132252399

196. ON Koc, J Day, M Nieder, SL Gerson, HM Lazarus, W Krivit: Allogeneic mesenchymal stem cell infusion for treatment of metachromatic leukodystrophy (MLD) and Hurler syndrome (MPS-IH). Bone Marrow Transplant 30, 215-222 (2002) DOI: $10.1038 /$ sj.bmt.1703650 
197. M Duijvestein, AC Vos, H Roelofs, ME Wildenberg, BB Wendrich, HW Verspaget, EM Kooy-Winkelaar, F Koning, JJ Zwaginga, $\mathrm{HH}$ Fidder, AP Verhaar, WE Fibbe, GR van den Brink, DW Hommes: Autologous bone marrow-derived mesenchymal stromal cell treatment for refractory luminal Crohn's disease: results of a phase I study. Gut 59, 1662-1669 (2010)

DOI: 10.1136/gut.2010.215152

198. N Perico, F Casiraghi, M Introna, E Gotti, M Todeschini, RA Cavinato, C Capelli, A Rambaldi, P Cassis, P Rizzo, M Cortinovis, M Marasa, J Golay, M Noris, G Remuzzi: Autologous mesenchymal stromal cells and kidney transplantation: a pilot study of safety and clinical feasibility. Clin J Am Soc Nephrol 6, 412-422 (2011)

DOI: 10.2215/CJN.04950610

199. JL Chan, KC Tang, AP Patel, LM Bonilla, N Pierobon, NM Ponzio, P Rameshwar: Antigen-presenting property of mesenchymal stem cells occurs during a narrow window at low levels of interferon-gamma. Blood 107, 4817-4824 (2006)

DOI: 10.1182/blood-2006-01-0057

200. GM Spaggiari, A Capobianco, H Abdelrazik, F Becchetti, MC Mingari, L Moretta: Mesenchymal stem cells inhibit natural killer-cell proliferation, cytotoxicity, and cytokine production: role of indoleamine 2,3-dioxygenase and prostaglandin E2. Blood 111, 1327-1333 (2008)

DOI: 10.1182/blood-2007-02-074997

201. XP Huang, Z Sun, Y Miyagi, H McDonald Kinkaid, L Zhang, RD Weisel, RK Li: Differentiation of allogeneic mesenchymal stem cells induces immunogenicity and limits their long-term benefits for myocardial repair. Circulation 122, 2419-2429 (2010)

DOI: $\quad 10.1161 / C I R C U L A T I O N A H A .110$. 955971

202. S Dhingra, P Li, XP Huang, J Guo, J Wu, A Mihic, SH Li, WF Zang, D Shen, RD Weisel, PK Singal, RK Li: Preserving prostaglandin E2 level prevents rejection of implanted allogeneic mesenchymal stem cells and restores postinfarction ventricular function. Circulation 128, S69-78 (2013)

DOI: $\quad$ 10.1161/CIRCULATIONAHA.112. 000324
203. JA Dixon, RC Gorman, RE Stroud, S Bouges, $\mathrm{H}$ Hirotsugu, JH Gorman, $3^{\text {rd }}$, TP Martens, S Itescu, MD Schuster, T Plappert, MG St John-Sutton, FG Spinale: Mesenchymal cell transplantation and myocardial remodeling after myocardial infarction. Circulation 120, S220-229 (2009)

DOI: $\quad$ 10.1161/CIRCULATIONAHA.108. 842302

204. S Medicetty, D Wiktor, N Lehman, A Raber, ZB Popovic, R Deans, AE Ting, MS Penn: Percutaneous adventitial delivery of allogeneic bone marrow-derived stem cells via infarctrelated artery improves long-term ventricular function in acute myocardial infarction. Cell Transplant 21, 1109-1120 (2012)

DOI: $10.3727 / 096368911 \times 603657$

205. H Hamamoto, JH Gorman, $3^{\text {rd }}$, LP Ryan, R Hinmon, TP Martens, MD Schuster, T Plappert, M Kiupel, MG St John-Sutton, S Itescu, RC Gorman: Allogeneic mesenchymal precursor cell therapy to limit remodeling after myocardial infarction: the effect of cell dosage. Ann Thorac Surg 87, 794-801 (2009) DOI: 10.1016/j.athoracsur.2008.11.057

206. N Eliopoulos, J Stagg, L Lejeune, S Pommey, J Galipeau: Allogeneic marrow stromal cells are immune rejected by MHC class I- and class II-mismatched recipient mice. Blood 106, 4057-4065 (2005)

DOI: 10.1182/blood-2005-03-1004

207. AJ Nauta, G Westerhuis, AB Kruisselbrink, EG Lurvink, R Willemze, WE Fibbe: Donor-derived mesenchymal stem cells are immunogenic in an allogeneic host and stimulate donor graft rejection in a nonmyeloablative setting. Blood 108, 2114-2120 (2006)

DOI: 10.1182/blood-2005-11-011650

208. AJ Poncelet, JVercruysse, ASaliez, P Gianello: Although pig allogeneic mesenchymal stem cells are not immunogenic in vitro, intracardiac injection elicits an immune response in vivo. Transplantation 83, 783-790 (2007) DOI: 10.1097/01.tp.0000258649.23081.a3

209. R Atoui, JF Asenjo, M Duong, G Chen, RC Chiu, D Shum-Tim: Marrow stromal cells as universal donor cells for myocardial regenerative therapy: their unique immune tolerance. Ann Thorac Surg 85, 571-579 (2008)

DOI: 10.1016/j.athoracsur.2007.10.034 
210. M Turner, S Leslie, NG Martin, M Peschanski, M Rao, CJ Taylor, A Trounson, D Turner, S Yamanaka, I Wilmut: Toward the development of a global induced pluripotent stem cell library. Cell Stem Cell 13, 382-384 (2013)

DOI: 10.1016/j.stem.2013.08.003

211. M Gnecchi, H He, OD Liang, LG Melo, F Morello, $\mathrm{H} \mathrm{Mu}, \mathrm{N}$ Noiseux, L Zhang, RE Pratt, JS Ingwall, VJ Dzau: Paracrine action accounts for marked protection of ischemic heart by Akt-modified mesenchymal stem cells. Nat Med 11, 367-368 (2005)

DOI: $10.1038 / \mathrm{nm} 0405-367$

212. C de Rham, J Villard: Potential and limitation of HLA-based banking of human pluripotent stem cells for cell therapy. J Immunol Res 2014, 518135 (2014)

DOI: $10.1155 / 2014 / 518135$

Key Words: Stem Cells, Mesenchymal Stem Cells, Endothelial Progenitor Cells, Cardiac Regeneration, Heart Failure, Diabetes, Metabolic Syndrome, Aging, Review

Send correspondence to: Elisa Gambini, Vascular Biology and Regenerative Medicine Unit, Centro Cardiologico Monzino, IRCCS, Via Carlo Parea 4, 20138 Milan, Italy. Tel: 390258002027, Fax: 390258002342. E-mail: elisa.gambini@ccfm.it 